\title{
Use of remote sensing and long-term in-situ time-series data in an integrated hydrological model of the Central Kalahari Basin, Southern Africa
}

\author{
Moiteela Lekula ${ }^{1,2}$ (D) Maciek W. Lubczynski ${ }^{1}$
}

Received: 5 June 2018 / Accepted: 17 December 2018 / Published online: 27 March 2019

(C) The Author(s) 2019

\begin{abstract}
Distributed numerical models, considered as optimal tools for groundwater resources management, have always been constrained by availability of spatio-temporal input data. This problem is particularly distinct in arid and semi-arid developing countries, characterized by large spatio-temporal variability of water fluxes but scarce ground-based monitoring networks. That problem can be mitigated by remote sensing (RS) methods, which nowadays are applicable for modelling not only surface-water but also groundwater resources, through rapidly increasing applications of integrated hydrological models (IHMs). This study shows implementation of various RS products in the IHM of the Central Kalahari Basin $\left(\sim 200 \mathrm{Mm}^{2}\right)$ multi-layered aquifer system, characterized by semi-arid climate and thick unsaturated zone, both enhancing evapotranspiration. The MODFLOW-NWT model with UZF1 package, accounting for variably saturated flow, was set up and calibrated in transient conditions throughout 13.5 years using borehole hydraulic heads as state variables and RS-based daily rainfall and potential evapotranspiration as driving forces. Other RS input data included: digital-elevation-model, land-use/land-cover and soils datasets. The model characterized spatio-temporal water flux dynamics, providing 13-year (2002-2014) daily and annual water balances, thereby evaluating groundwater-resource dynamics and replenishment. The balances showed the dominant role of evapotranspiration in restricting gross recharge to only a few $\mathrm{mm} \mathrm{yr}^{-1}$ and typically negative net recharge (median, $-1.5 \mathrm{~mm} \mathrm{yr}^{-1}$ ), varying from -3.6 (2013) to +3.0 (2006) $\mathrm{mm} \mathrm{yr}^{-1}$ (rainfall of 287 and $664 \mathrm{~mm} \mathrm{yr}^{-1}$ respectively) and implying systematic water-table decline. The rainfall, surface morphology, unsaturated zone thickness and vegetation type/density were primary determinants of the spatiotemporal net recharge distribution.
\end{abstract}

Keywords Groundwater/surface-water interaction $\cdot$ Remote sensing $\cdot$ Numerical modelling $\cdot$ Water balance $\cdot$ Namibia $\cdot$ Botswana

\section{Introduction}

Groundwater is often the only, but vulnerable, source of potable water in arid and semi-arid areas, hence it must be well evaluated and managed. Nowadays, distributed integrated

Maciek W. Lubczynski

m.w.lubczynski@utwente.nl

Moiteela Lekula

m.lekula@yahoo.com

1 Department of Water Resources, Faculty of Geo-information Science and Earth Observation (ITC), University of Twente, P.O. Box 217, 7500AE Enschede, The Netherlands

2 Department of Earth and Environmental Sciences, Botswana International University of Science and Technology (BIUST), Private Bag 16, Palapye, Botswana hydrological models (IHMs), coupling surface with groundwater processes, are considered optimal tools for groundwater resources management, but their reliability is largely constrained by the availability and quality of input data (Meijerink et al. 2007). The largest data problem is found in arid and semi-arid areas, because in those areas, ground-based monitoring networks are scarce (Brunner et al. 2007; Leblanc et al. 2007). That problem can be mitigated by remote sensing (RS) methods.

In recent years, RS has played an increasingly important role in providing spatio-temporal information for water resources evaluation and management (Coelho et al. 2017). Its applications in surface hydrology, including surface-water modelling, are already well known and typically include digital elevation derivatives, land use/cover, and spatio-temporal rainfall and evapotranspiration evaluations (Schmugge et al. 2002). However, the RS contribution to groundwater hydrology and groundwater resources evaluation is less distinct, so less well known. 
Standard published RS applications in groundwater hydrology have involved: assessment of groundwater recharge (e.g., Awan et al. 2013; Brunner et al. 2004; Coelho et al. 2017; Jasrotia et al. 2007; Khalaf and Donoghue 2012), surface-water/groundwater interaction (e.g., Bauer et al. 2006; Hassan et al. 2014; Leblanc et al. 2007; Sarma and Xu 2017), and groundwater storage (resources) evaluation and change (e.g., Henry et al. 2011; Rodell et al. 2007; Rodell and Famiglietti 2002; Taniguchi et al. 2011; Yeh et al. 2006). With recent advancement of IHMs, the RS contribution to such models is rapidly increasing, mainly because of continuously increasing amounts of downloadable RS-based hydrological products, for example, rainfall or potential evapotranspiration data.

The most complex models are those coupling atmospheric-land-energy processes (so-called land surface models, LSMs, or atmospheric models, AMs) with physically based models, integrating surface with subsurface processes (further referred to as the integrated hydrological model, IHM). Examples of such complex couplings include: (1) coupling of hydrological model Parallel Flow (ParFlow) IHM (Ashby and Falgout 1996; Kollet and Maxwell 2006) with a LSM called Common Land Model (Dai et al. 2003) referred as CLM.PF (Maxwell and Miller 2005; Rihani et al. 2010); (2) coupling of CATchment HYdrology (CATHY; Paniconi et al. 2003) IHM with a LSM called NoahMP (Niu et al. 2011) referred as CATHY/NoahMP (Niu et al. 2014) and (3) coupling of HydroGeoSphere IHM (Brunner and Simmons 2012; Therrien 1992; Therrien et al. 2006) with the Weather Research and Forecasting (WRF) AM (described in Davison et al. 2018), referred to as HGS/WRF (Davison et al. 2018).

Among the IHMs, there are complex models based on a three-dimensional (3D) solution of Richards' equation and models simplifying Richards' equation to simulate surface-water/groundwater interactions. Examples of the complex IHMs include the three models already mentioned (ParFlow, CATHY and HydroGeoSphere), as well as HYDRUS-3D (Šimůnek et al. 2012), MODHMS (Panday and Huyakorn 2004), and WASH123D (Yeh et al. 2003). All these IHMs are computationally demanding and require fine spatial and temporal discretization due to large nonlinearity of Richards' equation (Downer and Ogden 2004; Sheikh et al. 2009). The IHMs simplifying Richards' equation are more robust. For example, used worldwide in lots of surface-water/groundwater interaction studies, MIKE SHE (Danish Hydraulic Institute 1998), simplifies Richards' equation to one-dimension (1D), although it is still a very complex code, requiring a variety of skills such as hydrogeology, soil science, agronomy, computational hydraulics (Refsgaard 2010) and many kinds of data for spatial heterogeneity description (Ma et al. 2016). Similar to MIKE SHE is the Gridded Surface/Subsurface Hydrological Analysis (GSSHA) model (Downer and Ogden 2004), which also simplifies Richards' equation to $1 \mathrm{D}$.

Relatively simpler and computationally more efficient are models simplifying Richards' equation, not only to $1 \mathrm{D}$ but also simplifying vertical, variably saturated flow as driven only by the gravity potential gradient, i.e. ignoring negative potential gradients (Harter and Hopmans 2004; Niswonger and Prudic 2004; Smith and Hebbert 1983). Such a solution, applying the kinematic wave (KW) approximation of Richards' equation, solved by the method of characteristics, is, for example, proposed within the widely used (also in this study) Unsaturated-Zone Flow (UZF1) Package (Niswonger et al. 2006) under MODFLOW-NWT (Niswonger et al. 2011). In the regional-scale modelling, such as in this study, that simplification can even be advantageous, because the errors introduced by averaging or upscaling soil hydraulic parameters, makes the KW approximation of the Richards' equation and its solution comparable in accuracy, while the KW equation requires less input data and much less computational power (Bailey et al. 2013; Hassan et al. 2014; Morway et al. 2013). Besides, the MODFLOW related codes are public domain.

MODFLOW-NWT, with its surface-water/groundwater interaction packages, including UZF1 package, has already been applied worldwide, either directly or within the GSFLOW (Markstrom et al. 2008) IHM. Most of these applications focused on simulation of hydrological processes of surface-water/groundwater interactions (El Zehairy et al. 2018; Gong et al. 2012; Hassan et al. 2014; Huntington and Niswonger 2012) and climate change impact on groundwater resources (e.g., Gong et al. 2012; Hay et al. 2010; Huntington and Niswonger 2012; Surfleet and Tullos 2013; Surfleet et al. 2012). However, none of such applications has ever been dedicated to IHM simulation of a regional, multi-layered aquifer system with a very thick unsaturated zone such as the Central Kalahari Basin (CKB), integrating RS data and long-term insitu hydro-meteorological time-series data.

The main objectives of this study were: (1) to present the use of various RS products coupled with long-term in-situ monitoring data, as input of a regional-scale distributed numerical IHM of the CKB; (2) to characterize spatio-temporal water flux dynamics of a semi-arid, multi-layered aquifer system characterized with very thick unsaturated zone; and (3) to provide a long-term quantitative water-balance estimate of such a system, evaluating its groundwater resources.

The Central Kalahari Basin (CKB) was chosen as the study area because it not only complies with the aforementioned characteristics, but also because it hosts the most productive, important and exploited transboundary groundwater resources of the Karoo System Aquifer (SMEC and EHES 2006), the focus of interest of Botswana and potentially also of Namibia. 


\section{Data and methods}

\section{Study area and conceptual model}

The Central Kalahari Basin (CKB) study area (Fig. 1), occupies central Botswana $\left(\sim 181,000 \mathrm{~km}^{2}\right)$ and a small part $\left(\sim 14,000 \mathrm{~km}^{2}\right)$ of Eastern Namibia. It is a large-scale hydrogeological basin, which formerly was a catchment of the fossil Okwa-Mmone River system (de Vries 1984). It is nearly flat due to surficial accumulation of eolian sand, known as Kalahari Sand. About $90 \%$ of the CKB is occupied by Kalahari Desert, characterized by semi-arid to arid climate because of its position under the descending limb of the Hadley cell circulation (Batisani and Yarnal 2010).

The rainfall in the CKB is highly spatially and temporally variable (Lekula et al. 2018b; Obakeng et al. 2007), with localized showers (Bhalotra 1987; Lekula et al. 2018b). Almost all the rainfall, occurs from September to April, i.e. mainly during summer rainy season. The mean annual rainfall in the CKB ranges from $380 \mathrm{~mm} \mathrm{yr}^{-1}$ in the south-western, to $530 \mathrm{~mm} \mathrm{yr}^{-1}$ in the north-eastern side of the study area (Lekula et al. 2018b). Annual potential evapotranspiration in the $\mathrm{CKB}$ exceeds annual rainfall, ranging from 1,350 to $1,450 \mathrm{~mm}$ (Choudhury 1997). The majority of the study area is covered by savannah grassland, sparse shrubs and acacia trees, which increase their density towards the east. The CKB is sparsely inhabited by people, mainly at the fringes, with the interior part occupied by Central Kalahari Game Reserve.

The whole CKB study area is covered by a mantle of Kalahari Sand of variable thickness, ranging from a few meters in the west to $>60 \mathrm{~m}$ in the central and eastern part. In approximately two-thirds of the CKB area, the sand is underlain by rocks of Karoo Supergroup Formation, while the remaining third part is underlain by Pre-Karoo rocks (Lekula et al. 2018a). The principal aquifers are Lebung, Ecca, and Ghanzi Aquifers (SMEC and EHES 2006). It is remarkable that despite the deep occurrence of groundwater (typically $>60 \mathrm{~m}$ b.g.s.), in the majority of the CKB, the main regional groundwater flow follows topography, i.e. it is directed from the higher elevated areas along the water divides of the CKB in the west, south and east, towards the lowest depression area in the central part and towards the north-east of Makgadikgadi Pans (de Vries et al. 2000; Fig. 1). There are no permanent surface-water bodies in the CKB study area, thus de Vries et al.

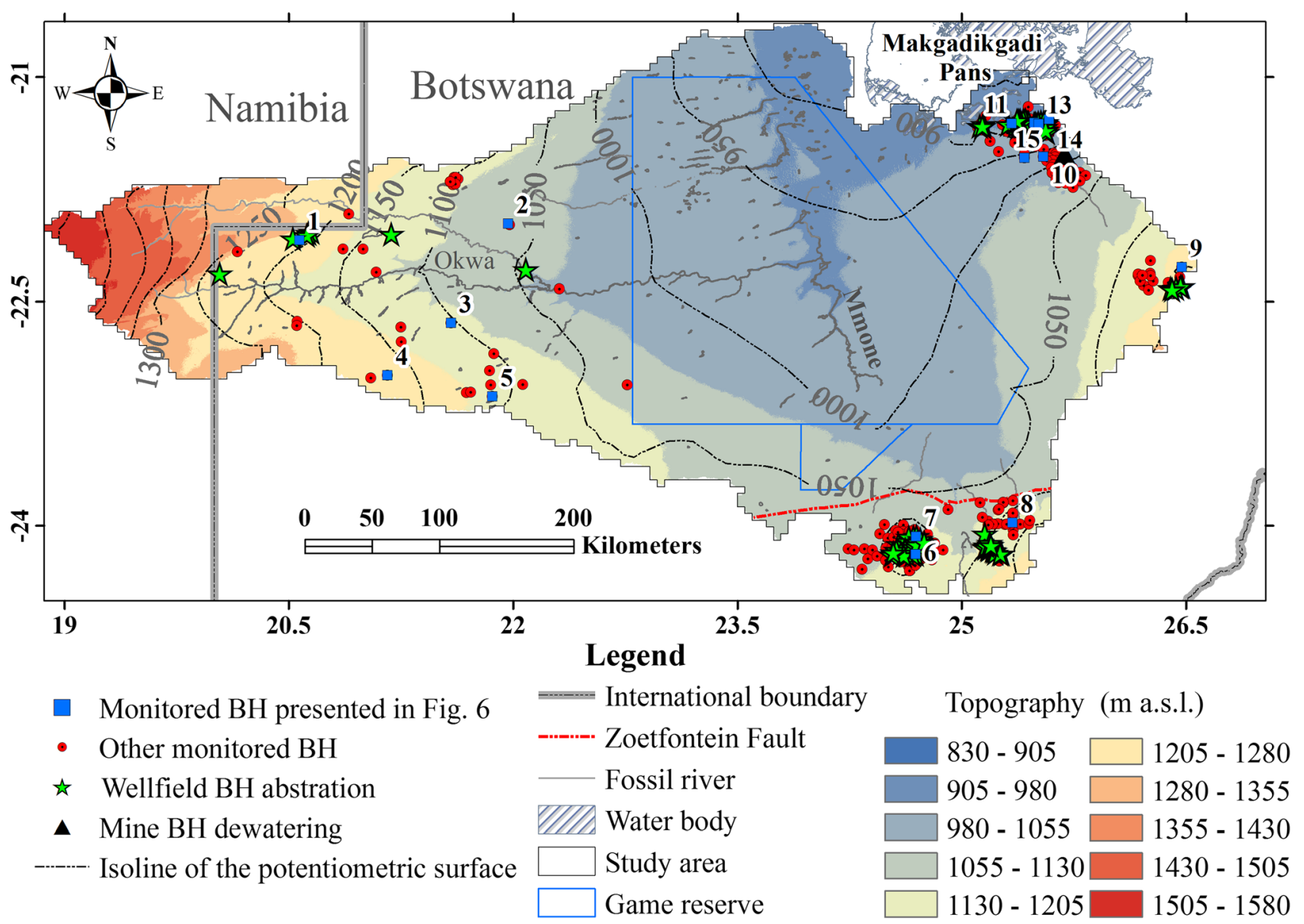

Fig. 1 Base map of the Central Kalahari Basin (CKB) including topography and simulated potentiometric surface on 31 December 2006 . BH borehole 
(2000) characterized it as a closed surface-water basin with an internal groundwater drainage system outflowing towards a natural discharge area of Makgadikgadi Pans (Fig. 1).

The hydrogeological framework of the CKB conceptual model presented by Lekula et al. (2018a) consists of six hydrostratigraphic units (HU, Fig. 2), including: (1) Kalahari Sand Unit (KSU); (2) Stormberg Basalt Aquitard (SBA); (3) Lebung Aquifer (LA); (4) Inter-Karoo Aquitard (IKA); (5) Ecca Aquifer (EA); and (6) Ghanzi Aquifer (GA).

The top Kalahari Sand Unit (KSU) is composed of sandy unconsolidated to semi-consolidated deposits with thickness ranging from $6 \mathrm{~m}$ in the western part to more than $100 \mathrm{~m}$ in the central and northern parts of the CKB (de Vries et al. 2000; Lekula et al. 2018a). The major part of the KSU thickness comprises the unsaturated zone, while the remaining, thin part at the KSU bottom, is saturated and spatially discontinuous. In a large part of the $\mathrm{CKB}$, the $\mathrm{KSU}$ is underlain by the second $\mathrm{HU}$, i.e. Stormberg Basalt Aquitard (SBA). In the majority of that area, the bottom of the KSU is saturated. The locally fractured SBA is composed of spatially nonuniform tholeiitic flood basalts (Smith 1984), characterized by abruptly changing thickness from 0 even up to $\sim 200 \mathrm{~m}$, as a result of intrusion or block faulting around major fault zones. Where the KSU is underlain by LA, EA or GA aquifer, it is hydraulically connected with that aquifer, forming one unconfined unit, typically with the water table in the aquifer underlying the KSU. The third HU, i.e. Lebung Aquifer (LA) consists of well-sorted, reddish to white, massive, but fractured sandstone, also nonuniformly distributed. Its spatially variable thickness ranges from $0 \mathrm{~m}$ in the north-western part of the CKB where it wedges out and in the southern part of the Zoetfontein Fault where significant uplifting has resulted in LA erosion, to $\sim 230 \mathrm{~m}$ in the northeastern and south-western parts of the CKB (Lekula et al. 2018a; SMEC and EHES 2006). The fourth HU, i.e. InterKaroo Aquitard (IKA), is composed of sedimentary, interchanging and nonuniformly distributed, mudstones and siltstones. Its thickness ranges from $0 \mathrm{~m}$ in the north-western and southern part of the CKB, to $\sim 250 \mathrm{~m}$ in the central part. The fifth HU, i.e. Ecca Aquifer (EA), consists of nonuniformly distributed sandstone, inter-layered with siltstone and carbonaceous mudstone (Smith 1984). Its thickness ranges from $0 \mathrm{~m}$ in the north-western $\mathrm{CKB}$ where it wedges out towards the Ghanzi Aquifer, to $\sim 290 \mathrm{~m}$ in the southern part of the Zoetfontein Fault (Fig. 1), where significant uplifting is followed by erosion of the SBA, LA and even IKA, so that EA is directly overlain by KSU (Lekula et al. 2018a; Smith 1984). The sixth HU, i.e. Ghanzi Aquifer (GA), consists of weakly metamorphosed, purple-red arkosic sandstone, siltstone, mudstone and rhythmite (Smith 1984), present only in the northwestern part of the $\mathrm{CKB}$. Its thickness ranges from $0 \mathrm{~m}$ in the centre of $\mathrm{CKB}$, to $\sim 230 \mathrm{~m}$ towards the north-western CKB. The basement, not included in the model, is represented by impermeable rocks underlying the deepest aquifer at given locations of the CKB flow system (Fig. 2).

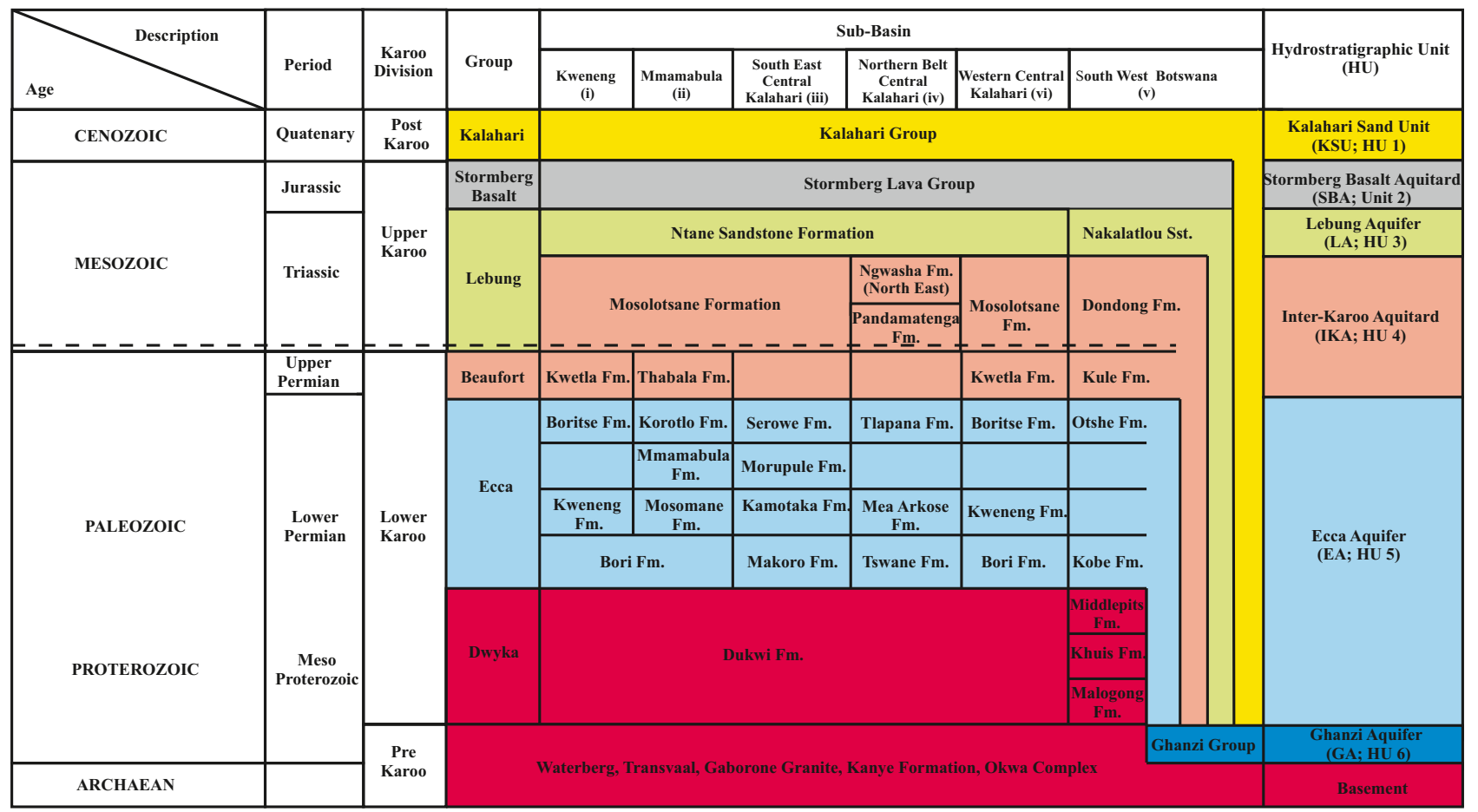

Fig. 2 Stratigraphy and hydrostratigraphy of Kalahari Group, Karoo Super-Group and Pre-Karoo in the CKB, after Lekula et al. (2018a); the colours correspond to hydrostratigraphic units and the dash-line defines a regional unconformity. Permission for reuse granted by Physics and Chemistry of the Earth, License No. 4470031150263 


\section{Numerical model}

The MODFLOW-NWT model with active UZF1 Package, further referred as MOD-UZF, was chosen as the IHM to be used in this study because: (1) it is a relatively simple but still integrated modelling solution, allowing one to compute groundwater fluxes (gross recharge, groundwater evapotranspiration and groundwater exfiltration) internally, based on unsaturated-zone parameterization and external input driving forces such as rainfall reduced by interception and potential evapotranspiration (Fig. 3), rather than assigning them arbitrarily, as is the case in a standard standalone groundwater model (Hassan et al. 2014); (2) the study area is pretty flat with a poor drainage network, active only shortly after long heavy rains, which justifies the use of MOD-UZF rather than more sophisticated IHM solution with complex surface modelling domain; (3) it is a computationally efficient IHM solution, optimal for large areas such as the CKB $\left(\sim 200,000 \mathrm{~km}^{2}\right)$; (4) it is public domain software with extensive web materials.

For pre- and post-processing of the MOD-UZF, the ModelMuse graphical user interface (Winston 2009) was used because: (1) it is public domain software; (2) it is easy and straightforward software with good technical support. Postprocessing of cell by cell water budgets for each $\mathrm{HU}$ or of a specific part of the model, was evaluated with ZONEBUDGET (Harbaugh 1990).

\section{Model setup}

A six-layer 3D regional-numerical model was built over the CKB area, following the hydrogeological conceptual model (Fig. 3) of Lekula et al. (2018a), in which six model layers directly corresponded to the six HUs as per Figs. 2 and 4. The top model boundary represented by topographic surface, was assigned using $90-\mathrm{m}$ spatial resolution digital elevation model data obtained from the Shuttle Radar Topography Mission (SRTM; Jarvis et al. 2008). Each subsequent layer boundary was defined by subtraction of the HU thicknesses, interpolated using borehole log data within the 3D geological model (Lekula et al. 2018a) developed in Rockworks 17 software (RockWare 2017), further referred to as Rockworks. Where HUs pinched out (Fig. 4), layers were extended throughout the model domain, applying a fictitious 1-m-thick layer, with hydraulic properties representative of the overlying layer, in order to have continuous hydraulic connections in all the six layers, as per the solution proposed by Anderson et al. (2015) and for example implemented by (Masterson et al. 2016).

In the first, KSU top layer, 1D-vertical, variably saturated flow between land surface and water table, was simulated by the UZF1 package. All the six model layers, including the upper KSU with partially unsaturated zone, were set as "convertible" to be able to simulate spatio-temporally varying groundwater flow in either confined or unconfined conditions, depending on the head position. A quadratic $5 \times 5-\mathrm{km}^{2}$ grid, consistent with the WGS84 ARC coordinate system in which the CKB falls entirely in one zone 10 was used, instead of the commonly used WGS 1984 UTM coordinate system, where the CKB falls in the two zones, 34 and 35 . Such grid size was found to be a trade-off between model computational time and model accuracy.

\section{Model input}

The input data for the CKB consisted of driving forces, parameters and state variables. Rainfall reduced by interception, further referred to as effective precipitation $\left(P_{\mathrm{e}}\right)$, is the main driving force of the MOD-UZF model. In this study, the spatio-temporally variable, daily satellite rainfall of Famine Early Warning System Network Rainfall Estimate v.2 (Herman et al. 1997), further referred as RFE, was downloaded from the United States Geological Survey (USGS) Famine Early Warning
Fig. 3 Schematic diagram of MOD-UZF setup for the CKB, where: $P$ precipitation; $I$ interception; $q_{\mathrm{ABS}}$ groundwater abstraction; $\mathrm{ET}_{\mathrm{g}}$ groundwater evapotranspiration; $\mathrm{ET}_{\mathrm{uz}}$ unsaturated zone evapotranspiration, $\mathrm{EXF}_{\mathrm{gw}}$ groundwater exfiltration to land surface; $R_{\mathrm{g}}$ gross recharge; $q_{\text {in }}$ lateral groundwater inflow; $q_{\text {out }}$ lateral groundwater outflow

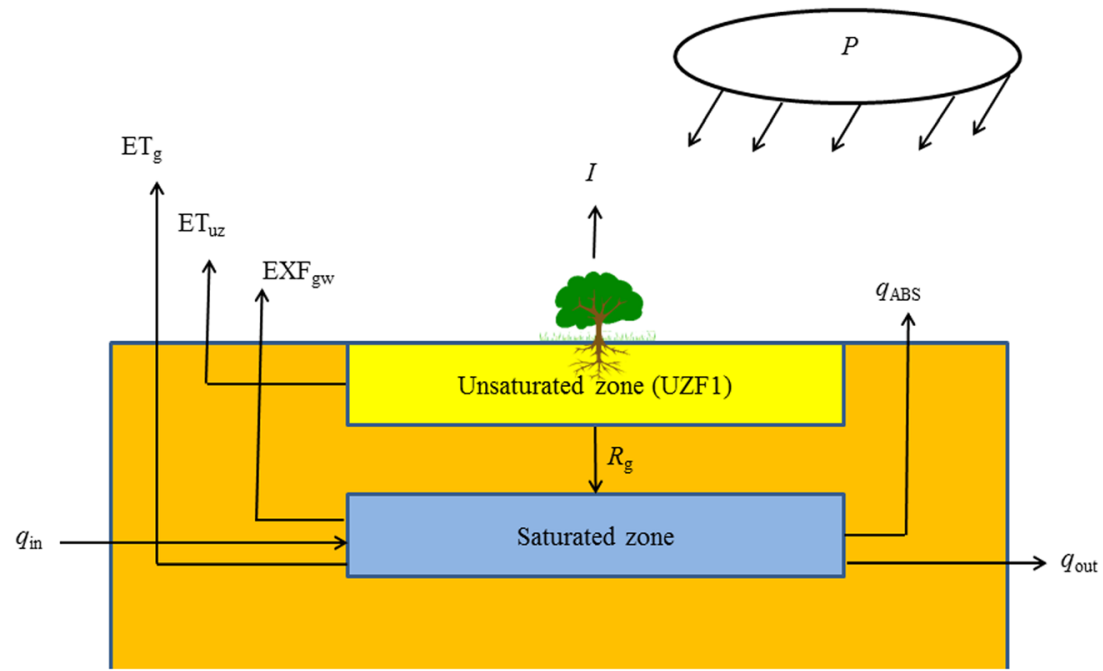




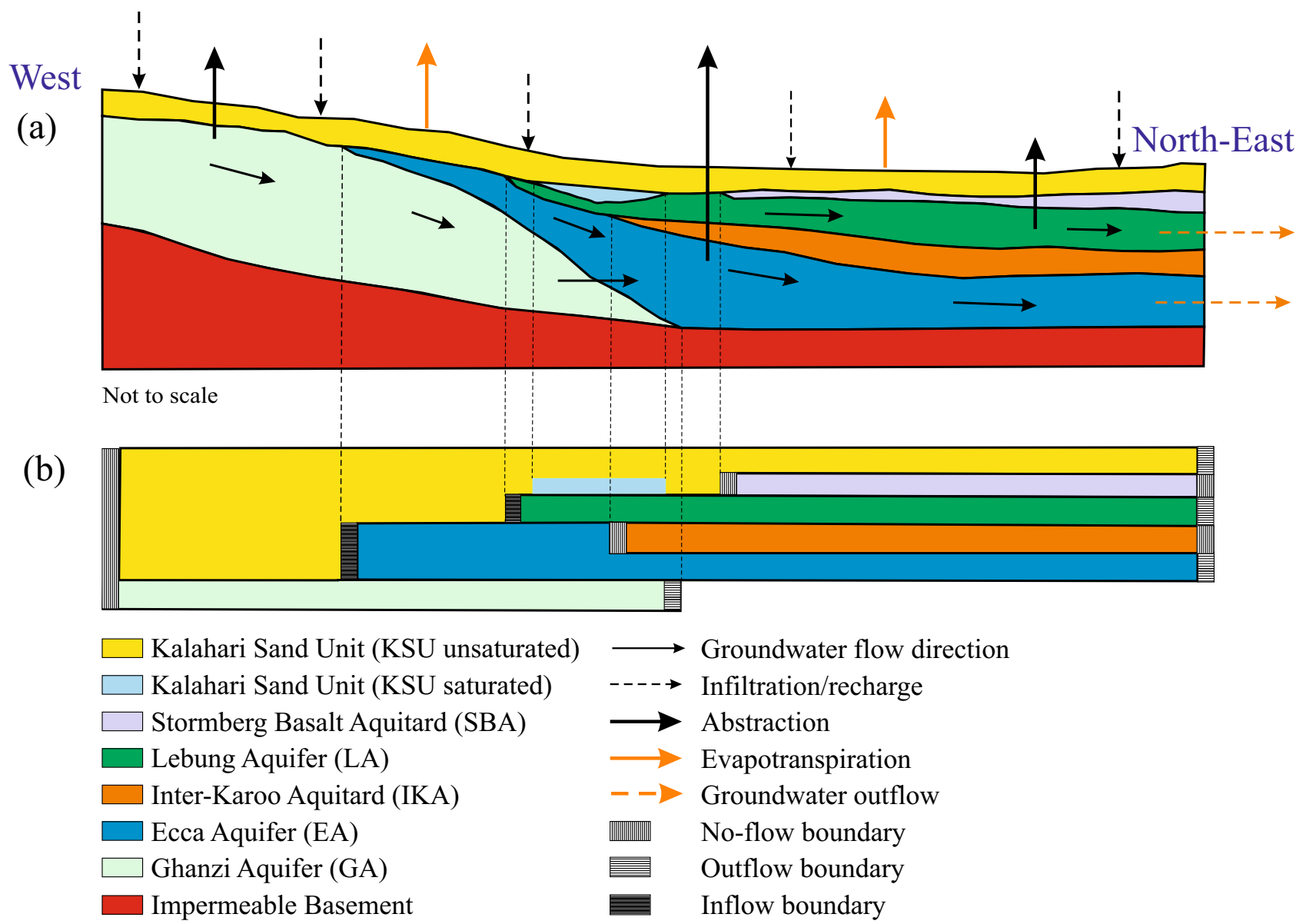

Fig. 4 A schematic diagram of: a hydrogeological conceptual model of the CKB; b numerical model schematization. (Lekula et al. 2018a); modified after permission for reuse granted by Physics and Chemistry of the Earth, License No. 4470031150263

System Network (FEWSNET) data portal (USGS 2007) for the period from 1 June 2001 to 31 December 2014. The choice of RFE was because of its superior daily rainfall detection capability in the CKB (Lekula et al. 2018b). The RFE of $0.1^{\circ}(\sim 11 \mathrm{~km})$ spatial resolution was resampled in ArcGIS to 5-km spatial resolution to match the model grid size, then converted to ASCII format and finally imported into ModelMuse.

The interception losses were assigned as spatially variable based on $1 \times 1-\mathrm{km}$ spatial resolution Land Use Land Cover (LULC) map (Loveland et al. 2000). Five land cover types were defined using information from Le Maitre et al. (1999), Miralles et al. (2010) and Werger and van Bruggen (1978), each with attributed interception losses defined in percentages of rainfall: bare soil and water bodies (0\%); grasslands (2\%); shrubs (4\%); savannah (a mixture of grassland, shrubs and forest) (6\%); forest (12\%). That map was reclassified according to the corresponding interception loss classes and resampled to $5 \times 5-\mathrm{km}$ spatial resolution, all done in ArcGIS. Finally, for each day of simulation, the interception loss map was subtracted from the rainfall map to obtain spatio-temporally variable infiltration rate, i.e. the effective precipitation $\left(P_{\mathrm{e}}\right)$, applied as the model driving force for each simulation day.
The second important driving force of the MOD-UZF is potential evapotranspiration (PET). The spatio-temporally variable daily PET data at $1^{0}(\sim 110 \mathrm{~km})$ spatial resolution was downloaded from the same USGS FEWSNET data portal as the rainfall and for the same period as the rainfall. The FEWSNET PET is calculated by USGS, using the PenmanMonteith equation formulation of Shuttleworth (1993) for reference crop evaporation, with external input parameters such as air temperature, atmospheric pressure, wind speed, relative humidity, and solar radiation, obtained from the Global Data Assimilation System (GDAS), generated every $6 \mathrm{~h}$ by the National Oceanic and Atmospheric Administration (NOAA), standardized in accordance with FAO Publ. 56 (Allen et al. 1998) and finally aggregated into daily totals. The FEWSNET PET was chosen because it was the only RS PET product available at daily time step for the CKB. The FEWSNET PET, further referred to as PET, was resampled in ArcGIS to $5-\mathrm{km}$ spatial resolution to match the model grid. The resampled daily PET, was finally converted to ASCII format and imported into ModelMuse.

The third driving force of the model was well abstractions, sourced from the two Debswana Diamond Mining Company Wellfields (Orapa and Jwaneng) and Water Utilities Corporation 
Table 1 CKB system parameterization: EXTWC evapotranspiration extinction water content; EXTDP evapotranspiration extinction depth; $K_{h}$ horizontal hydraulic conductivity; $K_{v}$ vertical hydraulic conductivity; $S_{y}$ specific yield; $S_{s}$ specific storage; Cond conductance; C parameter estimated from available data and adjusted during calibration; L parameter sourced from literature; F parameter estimated and averaged from available field tests

\begin{tabular}{|c|c|c|c|c|c|c|}
\hline ZONE & Parameter & Min value & Max value & Unit & Model & Source \\
\hline \multirow[t]{7}{*}{ Unsaturated zone } & $\theta_{\mathrm{s}}$ & 0.37 & 0.43 & $\mathrm{~m}^{3} \mathrm{~m}^{-3}$ & MOD-UZF (UZF1) & $\mathrm{L}$ \\
\hline & $\theta_{\mathrm{r}}$ & 0.05 & 0.15 & $\mathrm{~m}^{3} \mathrm{~m}^{-3}$ & MOD-UZF (UZF1) & $\mathrm{L}$ \\
\hline & $\theta_{\mathrm{i}}$ & 0.05 & 0.15 & $\mathrm{~m}^{3} \mathrm{~m}^{-3}$ & MOD-UZF (UZF1) & $\mathrm{L}$ \\
\hline & EXTWC & 0.06 & 0.16 & $\mathrm{~m}^{3} \mathrm{~m}^{-3}$ & MOD-UZF (UZF1) & $\mathrm{L}$ \\
\hline & EXTDP & 1 & 25 & $\mathrm{~m}$ & MOD-UZF (UZF1) & $\mathrm{L}$ \\
\hline & $\varepsilon$ & 3.5 & 3.5 & - & MOD-UZF (UZF1) & $\mathrm{L}$ \\
\hline & $K_{\mathrm{v}}$ & 1.1 & 1.96 & $\mathrm{~m} \mathrm{~d}^{-1}$ & MOD-UZF (UZF1) & $\mathrm{C}$ \\
\hline \multirow[t]{19}{*}{ Saturated zone } & $K_{\mathrm{h}}$ (layer 1) & 11 & 19.6 & $\mathrm{~m} \mathrm{~d}^{-1}$ & MOD-UZF & $\mathrm{C}$ \\
\hline & $K_{\mathrm{h}}$ (layer 2) & $3.1 \mathrm{E}-05$ & 0.009 & $\mathrm{~m} \mathrm{~d}^{-1}$ & MOD-UZF & $\mathrm{L}$ \\
\hline & $K_{\mathrm{h}}$ (layer 3) & 0.42 & 0.95 & $\mathrm{~m} \mathrm{~d}^{-1}$ & MOD-UZF & $\mathrm{C}$ \\
\hline & $K_{\mathrm{h}}$ (layer 4) & $1.02 \mathrm{E}-07$ & 0.004 & $\mathrm{~m} \mathrm{~d}^{-1}$ & MOD-UZF & $\mathrm{L}$ \\
\hline & $K_{\mathrm{h}}$ (layer 5) & 0.132 & 0.67 & $\mathrm{~m} \mathrm{~d}^{-1}$ & MOD-UZF & $\mathrm{C}$ \\
\hline & $K_{\mathrm{h}}$ (layer 6) & 0.585 & 0.96 & $\mathrm{~m} \mathrm{~d}^{-1}$ & MOD-UZF & $\mathrm{C}$ \\
\hline & $S_{\mathrm{y}}$ (layer 1) & 0.22 & 0.33 & - & MOD-UZF & $\mathrm{F}$ \\
\hline & $S_{\text {y }}$ (layer 2) & $1.0 \mathrm{E}-05$ & $1.0 \mathrm{E}-05$ & - & MOD-UZF & $\mathrm{F}$ \\
\hline & $S_{\text {y }}$ (layer 3) & 0.02 & 0.08 & - & MOD-UZF & $\mathrm{F}$ \\
\hline & $S_{\mathrm{y}}$ (layer 4) & $1.0 \mathrm{E}-06$ & $1.0 \mathrm{E}-06$ & - & MOD-UZF & $\mathrm{F}$ \\
\hline & $S_{\mathrm{y}}$ (layer 5) & 0.03 & 0.04 & - & MOD-UZF & $\mathrm{F}$ \\
\hline & $S_{\mathrm{y}}$ (layer 6) & 0.01 & 0.06 & - & MOD-UZF & $\mathrm{F}$ \\
\hline & $S_{\mathrm{s}}$ (layer 2) & $1.0 \mathrm{E}-09$ & $1.0 \mathrm{E}-09$ & $\mathrm{~m}^{-1}$ & MOD-UZF & $\mathrm{L}$ \\
\hline & $S_{\mathrm{s}}$ (layer 3) & $2.0 \mathrm{E}-06$ & $8.0 \mathrm{E}-06$ & $\mathrm{~m}^{-1}$ & MOD-UZF & $\mathrm{C}$ \\
\hline & $S_{\mathrm{s}}$ (layer 4) & $1.0 \mathrm{E}-09$ & $1.0 \mathrm{E}-09$ & $\mathrm{~m}^{-1}$ & MOD-UZF & $\mathrm{L}$ \\
\hline & $S_{\mathrm{s}}$ (layer 5) & $2.0 \mathrm{E}-06$ & $4.8 \mathrm{E}-06$ & $\mathrm{~m}^{-1}$ & MOD-UZF & $\mathrm{C}$ \\
\hline & $S_{\mathrm{s}}$ (layer 6) & $1.2 \mathrm{E}-06$ & $6.5 \mathrm{E}-06$ & $\mathrm{~m}^{-1}$ & MOD-UZF & $\mathrm{F}$ \\
\hline & Cond & 0.5 & 67 & $\mathrm{~m}^{2} \mathrm{~d}^{-1}$ & MOD-UZF (GHB) & $\mathrm{C}$ \\
\hline & Cond & 2 & 307 & $\mathrm{~m}^{2} \mathrm{~d}^{-1}$ & MOD-UZF (DRN) & $\mathrm{C}$ \\
\hline
\end{tabular}

Wellfields (Greater Ghanzi and Gaothobogwe areas). The abstraction rates were arranged according to the daily simulation time step.

The parameterization of the unsaturated and saturated zones is presented in Table 1 . The relation between unsaturated hydraulic conductivity and the unsaturated-zone water content was defined by the Brooks and Corey function (Brooks and Corey 1966; Eq. 1):

$K(\theta)=K_{\mathrm{v}}\left[\frac{\theta-\theta_{\mathrm{r}}}{\theta_{\mathrm{s}}-\theta_{\mathrm{r}}}\right]^{\varepsilon}$

where $K(\theta)$ is unsaturated hydraulic conductivity, $K_{\mathrm{v}}$ is vertical saturated hydraulic conductivity, $\theta$ is current volumetric water content, $\theta_{\mathrm{r}}$ is soil residual water content; $\theta_{\mathrm{s}}$ is soil saturated water content; and $\varepsilon$ is the Brooks and Corey exponent.

In the UZF1 Package, continuity between the unsaturated zone and saturated zone in the top unconfined aquifer is maintained through $S_{\mathrm{y}}$ estimated as $\theta_{\mathrm{s}}-\theta_{\mathrm{r}}$, where $\theta_{\mathrm{r}}$ approximates specific retention capacity (Niswonger et al.
2006). The $\theta_{\mathrm{r}}$ and $\theta_{\mathrm{s}}$ (Table 1 ) were defined as spatially variable input, with the help of the $1 \times 1-\mathrm{km}$ resolution Africa soil map data (Jones et al. 2013); for each soil class, $\theta_{\mathrm{r}}$ and $\theta_{\mathrm{s}}$ were assigned following studies by Carsel and Parrish (1988) and Joshua (1991) and then spatially aggregated into $5 \times 5-\mathrm{km}$ grid. The evapotranspiration extinction water content (EXTWC) was assigned as $\theta_{\mathrm{r}}+0.01$ and initial water content $\left(\theta_{\mathrm{i}}\right)$ as equal to $\theta_{\mathrm{r}}$. The UZF1 vertical hydraulic conductivity $\left(K_{\mathrm{v}}\right)$ was assigned as ten times lower than $K_{\mathrm{h}}$ of the first layer (Domenico and Schwartz 1998; SMEC and EHES 2006) and was adjusted in the calibration process. The Brooks and Corey exponent $(\varepsilon)$ was kept as default (Table 1).

The spatial distribution of EXTDP was defined as per the different vegetation types, following the $1 \times 1-\mathrm{km}$ spatial resolution of LULC classification (Loveland et al. 2000). The values of the EXTDP classes were assigned based on the areal contributions of plants with different rooting depths, deduced from Obakeng et al. (2007), Kleidon (2004) and Canadell et al. (1996) as: bare soil and water bodies $(0 \mathrm{~m})$; grasslands 
(2 m); shrubs (6 m); savannah (a mixture of grassland, shrubs and forest; $12 \mathrm{~m})$; forest $(25 \mathrm{~m})$. The $1 \times 1-\mathrm{km}$ EXTDP was imported to ModelMuse and averaged within the $5 \times 5-\mathrm{km}$ grid.

The system parameterization (Table 1) was based on the spatial distribution of aquifer parameters obtained from previous studies (Lekula et al. 2018a). The horizontal hydraulic conductivities $\left(K_{\mathrm{h}}\right)$ were derived from the aquifer transmissivity data, extracted from pumping tests of projects executed in the $\mathrm{CKB}$ and aquifer thicknesses deduced using Rockworks (Lekula et al. 2018a). The vertical hydraulic conductivities $\left(K_{\mathrm{v}}\right)$ of all the layers were assigned as ten times lower than $K_{\mathrm{h}}$ (Domenico and Schwartz 1998). The $K$-values were adjusted in the calibration process as per Table 1 . These were the basis for demarcating internally homogeneous and isotropic $K$-zones for the aquifers, i.e. for layer 1-26 zones, for layer 326 zones, for layer 5-27 zones and for layer 6-11 zones. The SBA and IKA aquitards were assigned with spatially uniform $K$-values. The zones of aquifer storage parameters, i.e. specific yield $\left(S_{\mathrm{y}}\right)$ and specific storage $\left(S_{\mathrm{s}}\right)$, were delineated the same way as $K$-zones, while their values were assigned following borehole lithology and various literature sources elaborated in Lekula et al. (2018a). The $S_{\mathrm{y}}$ and $S_{\mathrm{s}}$ were further calibrated in the transient simulation, mainly following expansion of the cones of depressions around the wellfields.

Based on the conceptual model of Lekula et al. (2018a), the following external boundary conditions (Fig. 5) were assigned for the CKB numerical model: (1) no-flow boundaries all around the $\mathrm{CKB}$, matching the Okwa-Mmone River Catchment boundary for the first KSU, while for the subsequent units, either at the contact with an impermeable unit or along groundwater flowlines (Lekula et al. 2018a); (2) the head-dependent inflow/outflow boundary assigned using MODFLOW General Head Boundary (GHB) Package (McDonald and Harbaugh 1988), to simulate lateral groundwater inflow or outflow (Fig. 5); and (3) the head dependent outflow boundary assigned using MODFLOW Drain (DRN) Package (McDonald and Harbaugh 1988), to simulate lateral groundwater outflow to the Makgadikgadi Pans in the northern part of the study area (Fig. 5). There is also an internal model boundary along the regional structural feature of the fifth hydrostratigraphic unit (EA) called Zoetfontein Fault (Figs. 1 and 5), which is simulated using the Horizontal Flow Barrier (HFB) Package (Hsieh and Freckleton 1993), applying thickness of $3 \mathrm{~m}$ and hydraulic conductivity, adjusted during the calibration process.

Groundwater levels converted to hydraulic heads were sourced from Department of Water Affairs (Botswana), Water Utilities Corporation (Botswana), Debswana Diamond Mining Company (Botswana) and Directorate of Water Resources Management (Namibia). The hydraulic heads were used as state variables in the model calibration. In the steadystate calibration, all the water levels in investigation boreholes (see Fig. 9 in Lekula et al. (2018a)) were used, while in transient state, only monitoring boreholes were used (Fig. 1).

\section{Model calibration and sensitivity analysis}

First, a steady-state model was developed and calibrated using 13.5-year means of daily driving forces and state variables (from 1 June 2001 to 31 December 2014) to initialize the transient model. However, the steady-state simulation did not provide satisfactory initial hydraulic heads and initial water contents $\left(\theta_{i}\right)$ to start transient simulation, resulting in unrealistically large gross recharge. Similar problem was also observed by Niswonger et al. (2006). To fix it, a 6-month warm-up (spin-up) period, lasting from 1 June 2001 until 31 December 2001, was applied; hence, the final transient model was calibrated with data from 1 January 2002 till 31 December 2014 applying daily stress periods and daily time steps.

For model calibration, the Newtonian solver (MODFLOWNWT) was used, applying the code option of "calculating groundwater heads even if below cell bottom" to prevent drying cells. The head tolerance was adjusted to $0.5 \mathrm{~m}$, the flux tolerance to $5,000 \mathrm{~m}^{3} \mathrm{~d}^{-1}$ and the model complexity, to "complex". All the remaining solver criteria were left as default settings. The model was calibrated manually because of its complexity; using optimization codes such as PEST (Doherty and Hunt 2010) or UCODE (Hill and Tiedeman 2006) turned to be computationally and time-wise too demanding. Besides, the manual, trial-and-error calibration allows users to better understand the model behaviour (Hassan et al. 2014).

The steady-state and transient model calibrations aimed at minimising the mean absolute error (MAE) and the root mean square error (RMSE) of the differences between the simulated and measured groundwater heads and also water balance discrepancies at each time step as per Eqs. (2) and (3). The calibration process was done in all six simulated layers, adjusting the initially assigned zones of hydraulic conductivity $\left(K_{\mathrm{h}}\right)$, mainly those with scarcity of pumping test data. In the same way, also zones of specific yield $\left(S_{\mathrm{y}}\right)$ and specific storage $\left(S_{\mathrm{s}}\right)$ were adjusted (Table 1). The complete information explaining which parameter was calibrated and which not, can be found in Table 1.

$\mathrm{MAE}=\frac{1}{n} \sum_{i=1}^{n}\left|H_{\mathrm{obs}}-H_{\mathrm{sim}}\right|$

$\mathrm{RMSE}=\sqrt{\frac{1}{n} \sum_{i=1}^{n}\left(H_{\mathrm{obs}}-H_{\mathrm{sim}}\right)^{2}}$

The sensitivity analysis mainly focused on testing sensitivity of fluxes representing water exchange between unsaturated and saturated zone, i.e. groundwater exfiltration $\left(\mathrm{EXF}_{\mathrm{gw}}\right)$, groundwater evapotranspiration $\left(\mathrm{ET}_{\mathrm{g}}\right)$, gross recharge $\left(R_{\mathrm{g}}\right)$ and net recharge $\left(R_{\mathrm{n}}\right)$, to changes in selected parameters. 

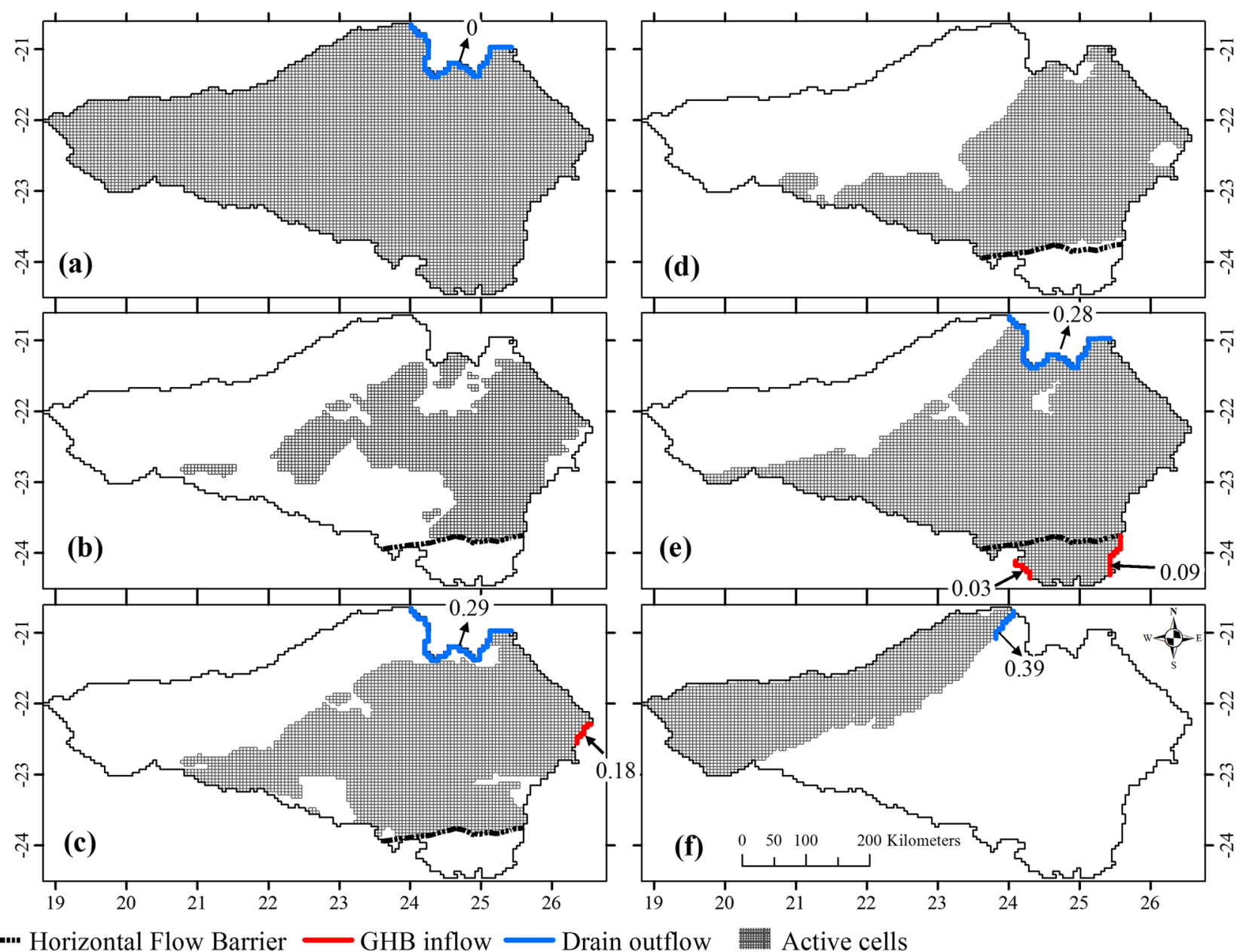

$-\cdot-$ Horizontal Flow Barrier - GHB inflow $\longrightarrow$ D
Fig. 5 Boundary conditions and layer pinch-out of the six layers: a Kalahari Sand unconfined layer; b Stormberg Basalt Aquitard; c Lebung Aquifer; d Inter-Karoo Aquitard; e Ecca Aquifer; f Ghanzi

Aquifer. Arrow and associated number indicate flow direction and 13-

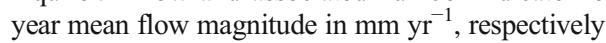

Various parameters were tested in that respect, to find those influencing the most surface-groundwater exchange; finally, three parameters were selected to be tested, i.e. vertical hydraulic conductivity $\left(K_{\mathrm{v}}\right)$ of the KSU, evapotranspiration extinction depth (EXTDP) and soil saturated water content $\left(\theta_{\mathrm{s}}\right)$.

\section{Water balances}

Water balancing of the multi-layered aquifer system, particularly when simulated with variably saturated models, can be a complex issue because of many interacting unsaturated and saturated zone components (Fig. 3). The water balance of the whole CKB model domain can be expressed as follows:

$P+q_{\mathrm{GHB}}=I+\mathrm{ET}_{\mathrm{sS}}+q_{\mathrm{ABS}}+q_{\mathrm{DRN}} \pm \Delta S$

where $P$ is precipitation, $q_{\mathrm{GHB}}$ is lateral groundwater inflow into the modelled area across the GHB boundary, $q_{\text {DRN }}$ is lateral groundwater outflow out of the modelled area across the DRN boundary, $I$ is canopy interception

loss, $\mathrm{ET}_{s s}$ is subsurface evapotranspiration, $q_{\mathrm{ABS}}$ is groundwater abstraction, and $\Delta S$ is total change in storage.

The $\mathrm{ET}_{S S}$ and $\Delta S$ can be expressed as follows:

$$
\begin{aligned}
& \mathrm{ET}_{\mathrm{ss}}=\mathrm{ET}_{\mathrm{uz}}+\mathrm{ET}_{\mathrm{g}} \\
& \Delta S=\Delta S_{\mathrm{uz}}+\Delta S_{\mathrm{g}}
\end{aligned}
$$

where $\mathrm{ET}_{\mathrm{uz}}$ is unsaturated zone evapotranspiration; $\mathrm{ET}_{\mathrm{g}}$ is groundwater evapotranspiration; $\Delta S_{\mathrm{uz}}$ is storage change in unsaturated zone; and $\Delta S_{\mathrm{g}}$ is storage change in the saturated zone.

The unsaturated zone water balance is expressed as:

$P_{\mathrm{a}}=P_{\mathrm{e}}+\mathrm{EXF}_{\mathrm{gw}}=R_{\mathrm{g}}+\mathrm{ET}_{\mathrm{uz}} \pm \Delta S_{\mathrm{uz}}$

where: $P_{\mathrm{e}}$ is effective precipitation $\left(P_{\mathrm{e}}=P-I\right), \mathrm{EXF}_{\mathrm{gw}}$ is groundwater exfiltration; $R_{\mathrm{g}}$ is gross recharge; $P_{\mathrm{a}}$ is actual infiltration (El-Zehairy et al. 2018).

The saturated zone water balance for all the simulated four layers can be expressed as follows: 
$R_{\mathrm{g}}+q_{\mathrm{GHB}}=q_{\mathrm{ABS}}+\mathrm{ET}_{\mathrm{g}}+q_{\mathrm{DRN}}+\mathrm{EXF}_{\mathrm{gw}} \pm \Delta S_{\mathrm{g}}$

The net recharge $\left(R_{\mathrm{n}}\right)$ is expressed as follows (Hassan et al. 2014):

$R_{\mathrm{n}}=R_{\mathrm{g}}-\mathrm{EXF}_{\mathrm{gw}}-E T_{\mathrm{g}}$

\section{Results and discussion}

\section{Model calibration}

The estimated and calibrated MOD-UZF hydraulic parameters are presented in Table 1. Figure 6 shows the comparison between the simulated and the measured heads for the 13-year calibration period for the selected representative boreholes as in Fig. 1. In general, there is a good match of the simulated with the measured temporal head patterns. The MAE values for the control points ranged from 0.02 to $2.70 \mathrm{~m}$ and the RMSE from 0.02 to $3.13 \mathrm{~m}$ (Eqs. (2 and 3)). The likely explanations for discrepancies between the simulated and the measured heads include: (1) averaging of the simulated heads within the $25-\mathrm{km}^{2}$ model cell; (2) potential errors in the abstraction data of piezometers/boreholes affected by wellfield groundwater abstraction (TP34J, W14 J, WF6_OB18O, WF5_OB10O, W47 J, WF2_OB1O and WF2_OB3O); (3) unrepresented heterogeneity within the $25-\mathrm{km}^{\overline{2}}$ model cell; (4) uncertainty in the measured water levels; (5) eventual errors in model parameterization.

It can be seen in Fig. 6 that there are wide ranges of slopes of the head declines. The particularly steep declines of groundwater heads are observed in boreholes W13J, W43J and TP34J located in the wellfield operated by Debswana Diamond Mining
Company (DDMC) in Jwaneng and in boreholes EB17O, WF2 OB10 and WF6 OB18O, also operated by DDMC, but in Orapa. The heads in areas outside the wellfields' influences (BH4743, BH7763, BH7764, BH9294, BH9297 and BH10224) also decline but with substantially gentler slopes. These declines are because the Kalahari area is affected by: (1) relatively low rainfall within the 13-year simulation period; (2) substantial $\mathrm{ET}_{\mathrm{uz}}$ due to large PET and a thick unsaturated zone restricting rainfall infiltration and recharge; and (3) considerable $\mathrm{ET}_{\mathrm{g}}$ due to groundwater uptake by deep rooted trees (Alaghmand et al. 2014; Obakeng et al. 2007), and possibly also due to direct groundwater evaporation from the water table (Balugani et al. 2016), both reducing net recharge and as such declining the water table and the groundwater resources.

The general head decline throughout the 13-year simulation period shows that the relatively low $R_{\mathrm{g}}$ was not able to compensate groundwater discharge occurring mainly by $\mathrm{ET}_{\mathrm{g}}$ (Lubczynski 2000; Lubczynski 2009) and by lateral groundwater outflow while only marginally by abstractions for livestock watering and by $\mathrm{EXF}_{\mathrm{gw}}$. In the areas affected by mine groundwater abstractions, that disproportion was much more distinct.

In the Kalahari, substantial replenishment of groundwater resources, on average, occurs only once per decade, in response to exceptionally high rainfall years (Lubczynski 2011, 2009; Obakeng et al. 2007; Wanke et al. 2008), while within this study period, there was no such rainfall year. The last exceptionally high rainfall year and aquifer replenishment was in the wet season of 1999/2000 characterized by rainfall of $970 \mathrm{~mm} \mathrm{yr}^{-1}$ (Obakeng et al. 2007), i.e. before this study simulation period. Since then, the CKB heads have declining trend as can be seen in Fig. 6.

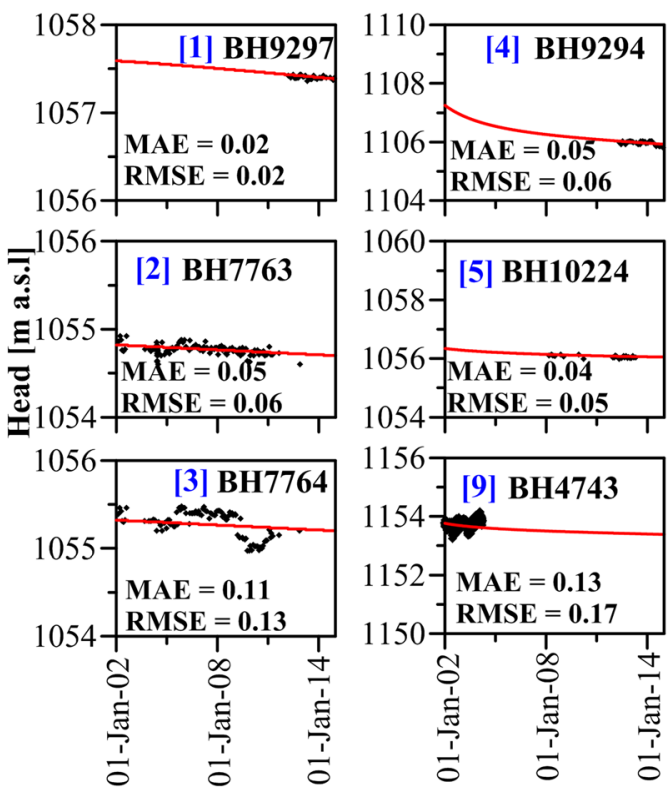

Fig. 6 Simulated and observed daily variability of selected groundwater piezometric heads; the locations of monitoring boreholes can be found in Fig. 1. The calibrated piezometers are grouped into five columns; note
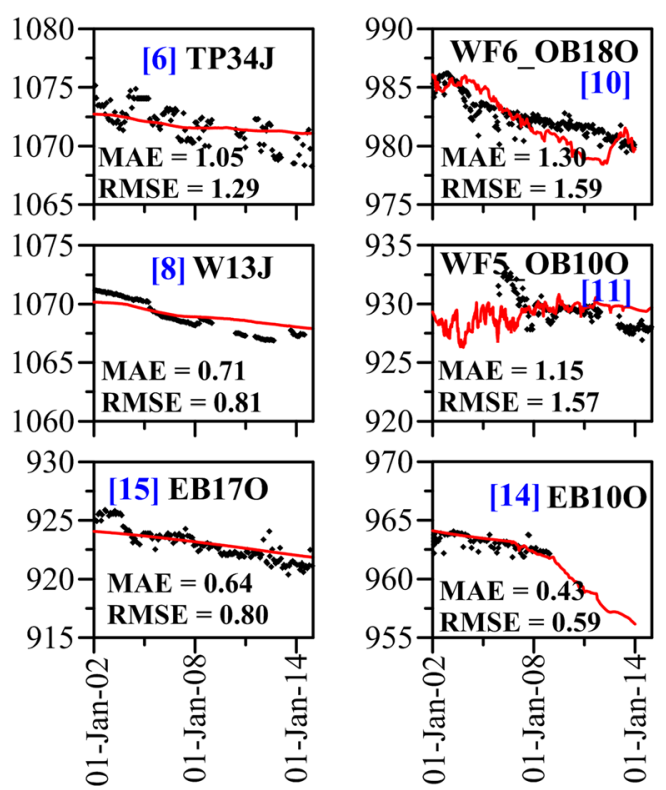

that within each column with three graphs, the axial head ranges are the same, but between columns, they are different 


\section{Water balances}

The yearly means of water balance components of the whole model domain per each of the 13 simulated hydrological years are presented in Table 2, while the 13-year means per each HU, presenting quantitative groundwater exchange between the six layers, are shown in the schematic block-diagram in Fig. 7. Note that in the CKB, the hydrological year starts from 1 September of the previous year and ends 31 August of the analysed year. The 13year mean water balance of the whole model domain (Table 2) as per Eq. (4) consists of: $P=458.91 \mathrm{~mm} \mathrm{yr}^{-1}$, $I=9.18 \mathrm{~mm} \mathrm{yr}^{-1}(2.00 \%$ of $P), q_{\mathrm{GHB}}=0.30 \mathrm{~mm} \mathrm{yr}^{-1}$ $(0.07 \%$ of $P), \mathrm{ET}_{\mathrm{ss}}=436.36 \mathrm{~mm} \mathrm{yr}^{-1}(95.09 \%$ of $P)$, $q_{\mathrm{ABS}}=0.22 \mathrm{~mm} \mathrm{yr}^{-1}(0.05 \%$ of $P), q_{\mathrm{DRN}}=0.94(0.20 \%$ of $P$ ) and the positive $\Delta S=12.52 \mathrm{~mm} \mathrm{yr}^{-1}(2.73 \%$ of $P$ ).

As the $\mathrm{EXF}_{\mathrm{gw}}$ in the $\mathrm{CKB}$ is negligible, the input into the unsaturated zone (Eq. (7)) consists only of $P_{\mathrm{e}}\left(449.73 \mathrm{~mm} \mathrm{yr}^{-1}\right)$. As a consequence, the $P_{\mathrm{a}}$ is equal to $P_{\mathrm{e}}$, which is characteristic for the investigated CKB study area, but likely also for other similar study areas with thick unsaturated zone. The output of the unsaturated zone water balance (Eq. 7) is dominated by $\mathrm{ET}_{\mathrm{uz}}$ (433.24 $\mathrm{mm} \mathrm{yr}^{-1}, 96.33 \%$ of $P_{\mathrm{e}}$ ), so only $1.87 \mathrm{~mm} \mathrm{yr}^{-1}(0.42 \%$ of $P_{\mathrm{e}}$ ) percolates down and recharges the saturated zone as $R_{\mathrm{g}}$, while the $\Delta S_{\mathrm{uz}}\left(14.62 \mathrm{~mm} \mathrm{yr}^{-1}\right)$ accounts for $3.19 \%$ of $P_{\mathrm{e}}$. Such dominance of the $\mathrm{ET}_{\mathrm{uz}}$, as compared to $R_{\mathrm{g}}$, is due to the thick Kalahari unsaturated zone, which favours $\mathrm{ET}_{\mathrm{uz}}$ and limits $R_{\mathrm{g}}$ to extremely wet seasons with large rain showers.
The input of the saturated zone water balance (Eqn (8)) consists of $R_{\mathrm{g}}\left(1.87 \mathrm{~mm} \mathrm{yr}^{-1}\right)$ and $q_{\mathrm{GHB}}\left(0.30 \mathrm{~mm} \mathrm{yr}^{-1}\right)$, while the output is dominated by $\mathrm{ET}_{\mathrm{g}}\left(3.12 \mathrm{~mm} \mathrm{yr}^{-1}\right)$, followed by $q_{\mathrm{DRN}}$ $\left(0.94 \mathrm{~mm} \mathrm{yr}^{-1}\right)$ reflecting lateral groundwater outflow and $q_{\mathrm{ABS}}$ $\left(0.22 \mathrm{~mm} \mathrm{yr}^{-1}\right)$. In the 13 investigated years, in the CKB, there was dominance of groundwater output as compared to input, which is reflected by the negative mean $\Delta S_{\mathrm{g}}\left(-2.11 \mathrm{~mm} \mathrm{yr}^{-1}\right)$, as only in one hydrological year (2006) with the largest rainfall of $664.45 \mathrm{~mm} \mathrm{yr}^{-1}$, was the $\Delta S_{\mathrm{g}}$ positive. This also explains the declining water table within the 13 simulated years.

The $R_{\mathrm{n}}$ was estimated as $R_{\mathrm{g}}-\mathrm{ET}_{\mathrm{g}}$ (Eq. 9) because $\mathrm{EXF}_{\mathrm{gw}} \sim 0$. The positive $R_{\mathrm{n}}$ indicates $R_{\mathrm{g}}>\mathrm{ET}$, and the negative $R_{\mathrm{n}}$ indicates $R_{\mathrm{g}}<\mathrm{ET}_{\mathrm{g}}$. Throughout the 13 hydrological years of the model simulation (Table 2), the $R_{\mathrm{n}}$ was typically negative, except for the 2 years with rainfall distinctly above-average, i.e. 2006 when $P=664.45 \mathrm{~mm} \mathrm{yr}^{-1}$ and $R_{\mathrm{n}}=3.42 \mathrm{~mm} \mathrm{yr}^{-1}$ and 2014 when $P=$ $605.90 \mathrm{~mm} \mathrm{yr}^{-1}$ and $R_{\mathrm{n}}=0.98 \mathrm{~mm} \mathrm{yr}^{-1}$. However, these two, relatively wet years could not compensate the remaining 11 years with negative $R_{\mathrm{n}}$, so the 13 -year mean $R_{\mathrm{n}}=-1.25 \mathrm{~mm} \mathrm{yr}^{-1}$. It is interesting that the largest yearly $R_{\mathrm{n}}$ (2006) coincided, as expected, with the largest $P$ and $R_{\mathrm{g}}$, but, unexpectedly, the lowest $R_{\mathrm{n}}$ (2002) coincided with the highest $\mathrm{ET}_{\mathrm{g}}$, not with the lowest $P$ and $R_{\mathrm{g}}$. The simulated $\mathrm{ET}_{\mathrm{g}}$ was the highest in 2002, because at the beginning of the simulation period, the water table was still pretty high after the replenishment in the extremely wet season of 2000 (Obakeng et al. 2007). Unfortunately, there were no sufficient data available in this study to start the model simulation from that year 2000 or earlier.

Table 2 A 13-hydrological-year annual water balance of the Central Kalahari Basin as per Eqs. (4), (7) and (8). All values are in $\mathrm{mm} \mathrm{yr}^{-1}$

\begin{tabular}{|c|c|c|c|c|c|c|c|c|c|c|c|c|c|c|}
\hline Hydrological year & $P$ & $P_{\mathrm{e}}$ & $I$ & $\mathrm{ET}_{\mathrm{ss}}$ & $\mathrm{ET}_{\mathrm{uz}}$ & $\mathrm{ET}_{\mathrm{g}}$ & $R_{\mathrm{g}}$ & $R_{\mathrm{n}}$ & $q_{\mathrm{GHB}}$ & $q_{\text {DRN }}$ & $q_{\mathrm{ABS}}$ & $\Delta S$ & $\Delta S_{\mathrm{uz}}$ & $\Delta S_{\mathrm{g}}$ \\
\hline 2002 & 445.40 & 436.49 & 8.91 & 413.34 & 408.00 & 5.34 & 1.88 & -3.46 & 0.30 & 0.94 & 0.22 & 22.29 & 26.61 & -4.32 \\
\hline 2003 & 357.29 & 350.14 & 7.15 & 364.99 & 361.10 & 3.88 & 0.66 & -3.22 & 0.30 & 0.94 & 0.22 & -15.70 & -11.63 & -4.08 \\
\hline 2004 & 439.49 & 430.70 & 8.79 & 419.82 & 416.91 & 2.91 & 1.42 & -1.49 & 0.30 & 0.95 & 0.22 & 10.02 & 12.37 & -2.35 \\
\hline 2005 & 386.60 & 378.87 & 7.73 & 383.38 & 380.57 & 2.82 & 0.97 & -1.85 & 0.30 & 0.94 & 0.22 & -5.38 & -2.67 & -2.71 \\
\hline 2006 & 664.45 & 651.16 & 13.29 & 553.78 & 550.98 & 2.81 & 6.23 & 3.42 & 0.30 & 0.94 & 0.22 & 96.51 & 93.96 & 2.55 \\
\hline 2007 & 330.48 & 323.87 & 6.61 & 329.45 & 324.67 & 4.78 & 1.52 & -3.26 & 0.30 & 0.94 & 0.22 & -6.43 & -2.32 & -4.12 \\
\hline 2008 & 483.41 & 473.74 & 9.67 & 473.55 & 470.23 & 3.31 & 1.33 & -1.98 & 0.30 & 0.94 & 0.22 & -0.67 & 2.17 & -2.84 \\
\hline 2009 & 510.24 & 500.04 & 10.20 & 489.85 & 487.13 & 2.72 & 1.40 & -1.32 & 0.30 & 0.94 & 0.22 & 9.33 & 11.51 & -2.18 \\
\hline 2010 & 556.79 & 545.65 & 11.14 & 543.24 & 540.92 & 2.32 & 1.55 & -0.78 & 0.30 & 0.94 & 0.23 & 1.54 & 3.19 & -1.65 \\
\hline 2011 & 590.72 & 578.91 & 11.81 & 567.16 & 564.79 & 2.37 & 2.02 & -0.35 & 0.30 & 0.94 & 0.22 & 10.89 & 12.11 & -1.21 \\
\hline 2012 & 307.21 & 301.07 & 6.14 & 304.30 & 301.38 & 2.92 & 1.29 & -1.63 & 0.30 & 0.94 & 0.21 & -4.07 & -1.60 & -2.48 \\
\hline 2013 & 287.84 & 282.08 & 5.76 & 284.00 & 281.62 & 2.38 & 1.09 & -1.29 & 0.30 & 0.94 & 0.21 & -2.76 & -0.63 & -2.14 \\
\hline 2014 & 605.90 & 593.78 & 12.12 & 545.77 & 543.76 & 2.01 & 2.99 & 0.98 & 0.30 & 0.94 & 0.22 & 47.15 & 47.03 & 0.12 \\
\hline \multicolumn{15}{|l|}{ Statistics } \\
\hline Mean & 458.91 & 449.73 & 9.18 & 436.36 & 433.24 & 3.12 & 1.87 & -1.25 & 0.30 & 0.94 & 0.22 & 12.52 & 14.62 & -2.11 \\
\hline Median & 445.40 & 436.49 & 8.91 & 419.82 & 416.91 & 2.82 & 1.42 & -1.49 & 0.30 & 0.94 & 0.22 & 1.54 & 3.19 & -2.35 \\
\hline Maximum & 664.45 & 651.16 & 13.29 & 567.16 & 564.79 & 5.34 & 6.23 & 3.42 & 0.30 & 0.95 & 0.23 & 96.51 & 93.96 & 2.55 \\
\hline Standard deviation & 122.11 & 119.67 & 2.44 & 99.72 & 100.12 & 0.99 & 1.43 & 1.86 & 0.00 & 0.00 & 0.01 & 29.79 & 28.23 & 1.86 \\
\hline Minimum & 287.84 & 282.08 & 5.76 & 284.00 & 281.62 & 2.01 & 0.66 & -3.46 & 0.30 & 0.94 & 0.21 & -15.70 & -11.63 & -4.32 \\
\hline
\end{tabular}

The hydrological year starts from 1 September of the previous year and ends 31 August of the analysed year 


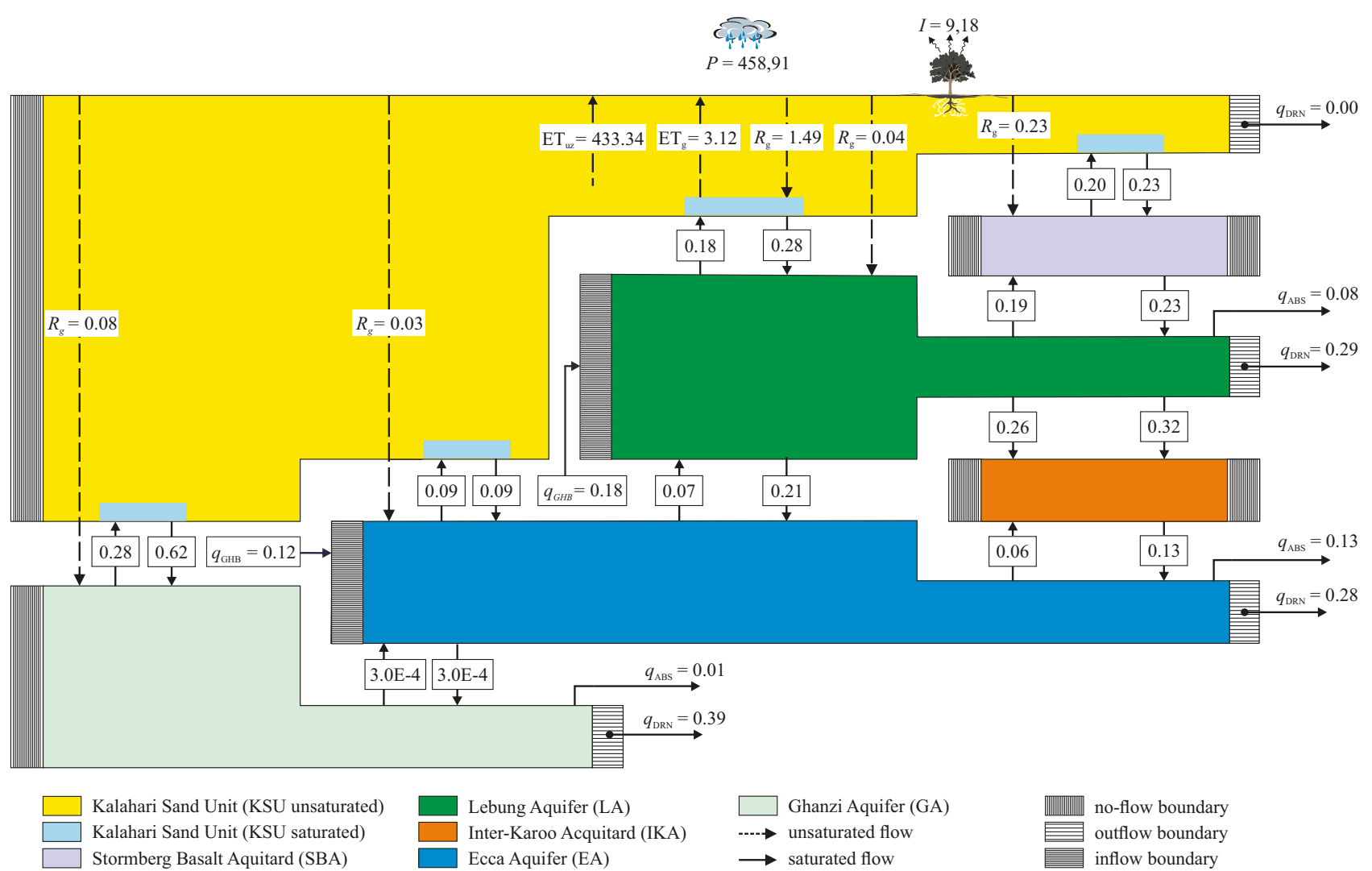

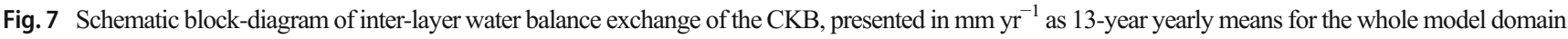

The lateral and vertical water flux exchanges through the six layers of the CKB are presented in Fig. 7 as 13-year means. In that diagram, each layer receives a number of input and output water fluxes, and the difference between them per layer represents its storage change. The presented water balance is pretty complex because of the very thick top KSU layer, redistributing rainfall water into various underlying layers and partitioning that water between $R_{\mathrm{g}}, \mathrm{ET}_{\mathrm{uz}}$ and $\mathrm{ET}_{\mathrm{g}}$. That complexity is also because of the complex structural geology and hydrogeology of the simulated area, with step-wise pinching out layers underlying KSU, which implies complex water flux exchanges between layers. For example, the $R_{\mathrm{g}}$, consists of five $R_{\mathrm{g}}$-components (Fig. 7), each addressing a different layer and each constrained by the presence of the shallowest, unconfined water table, located in one of the following layers; these $\mathrm{R}_{\mathrm{g}}$-components are: $1.49 \mathrm{~mm} \mathrm{yr}^{-1}$ to saturated KSU, $0.23 \mathrm{~mm} \mathrm{yr}^{-1}$ to SBA, $0.04 \mathrm{~mm} \mathrm{yr}^{-1}$ to LA, $0.03 \mathrm{~mm} \mathrm{yr}^{-1}$ to EA and $0.08 \mathrm{~mm} \mathrm{yr}^{-1}$ to GA, all five summing up to total of $1.87 \mathrm{~mm} \mathrm{yr}^{-1}$ (Table 2).

The total $R_{\mathrm{g}}$ was deduced directly from the MOD-UZF water budget output; however, the $R_{\mathrm{g}}$ components were defined indirectly by delineation of water budget zones with ZONEBUDGET postprocessor in layers underlying fully unsaturated KSU and by calculating downward water fluxes in those zones. Such an additional, indirect calculation protocol was applied, because the current UZF1 package, estimates $R_{\mathrm{g}}$ only within the water-table extent of the layer to which the
UZF1 Package is assigned-in this study case, the KSU. Considering $\mathrm{ET}_{\mathrm{g}}$, there was no analogic water budgeting problem, because the EXTDP was everywhere less than the KSU thickness, while the $\mathrm{EXF}_{\mathrm{gw}}$ was negligible.

Considering external groundwater exchange with $\mathrm{CKB}$ (Fig. 7), the lateral groundwater inflow enters LA from the east $\left(0.18 \mathrm{~mm} \mathrm{yr}^{-1}\right)$ and the EA from the two sides in the south $\left(0.03+0.09 \mathrm{~mm} \mathrm{yr}^{-1}\right)$ as shown in Fig. 5. The presence of these lateral inflows (defined in the model throughout the GHB boundary condition) rejected the hydrogeological conceptual model hypothesis that the CKB is a fully isolated basin (Lekula et al. 2018a), although the simulated inflows were pretty low, and possibly triggered by the wellfields' abstractions. The north-eastern lateral groundwater outflows towards Makgadikgadi Pans were (Fig. 5): (1) in KSU, negligible; (2) in LA, $0.29 \mathrm{~mm} \mathrm{yr}^{-1}$, so more than lateral input to LA; (3) in EA, $0.28 \mathrm{~mm} \mathrm{yr}^{-1}$, so much more than lateral input to EA; and (4) in GA, which did not have any lateral input, the groundwater outflow was the largest $\left(0.39 \mathrm{~mm} \mathrm{yr}^{-1}\right)$ mainly because of the largest, positive balance of the interlayer, water flux exchange with the the saturated KSU (Fig. 7), where the input from the saturated KSU was $0.62 \mathrm{~mm} \mathrm{yr}^{-1}$, while the output, only $0.28 \mathrm{~mm} \mathrm{yr}^{-1}$. The large downward water input was because of the peripheral GA position with respect to the CKB and relatively large area of saturated KSU being in direct hydraulic contact with GA (Lekula et al. 2018a). In contrast, the lowest interlayer water 
flux exchange difference between different layers was observed between KSU and EA where the same $0.09 \mathrm{~mm} \mathrm{yr}^{-1}$ went in and out between the layers. Surprising is relatively large groundwater exchange across the SBA (Fig. 7). This basaltic layer has low storage but pretty high vertical permeability due to locally occurring vertical fracture zones. The 13-year mean groundwater abstractions $\left(q_{\mathrm{ABS}}\right)$ in all the three aquifers look pretty small as compared to other water fluxes, because they are referenced to the whole CKB model domain $\left(\sim 200 \mathrm{Mm}^{2}\right)$, while at the local scales, these abstractions are significant.

\section{Spatial variability of groundwater fluxes}

Figure 8a presents the spatial variability of $R_{\mathrm{g}}, \mathrm{ET}_{\mathrm{g}}$ and $R_{\mathrm{n}}$ in the wettest simulated hydrological year (2006) and Fig. 8b in the driest year, 2013 (Table 2). It can be seen that in both years, $R_{\mathrm{g}}$, $\mathrm{ET}_{\mathrm{g}}$ and $R_{\mathrm{n}}$ were highly localized, being limited to small areas such as fossil river channels and depressions (Fig. 8a). This is in agreement with de Vries et al. (2000), who also observed only locally enhanced recharge of up to $50 \mathrm{~mm} \mathrm{yr}^{-1}$ in pans and fossil valleys in the southern part of the CKB. The spatial restriction of groundwater fluxes to relief depressions and fossil channels is mainly due to periodic rainfall water storing in these locations, to local increase of soil moisture and to shallowing of water table, all creating favourable conditions for $R_{\mathrm{g}}$, although also enhancing $\mathrm{ET}_{\mathrm{uz}}$ and $\mathrm{ET}_{\mathrm{g}}$.

The $R_{\mathrm{g}}\left(6.23 \mathrm{~mm} \mathrm{yr}^{-1}\right)$ in the 2006 hydrological year, was larger and covered a much bigger area than the $R_{\mathrm{g}}(1.09 \mathrm{~mm}$ $\mathrm{yr}^{-1}$ ) in 2013 (Fig. 8b), while the $\mathrm{ET}_{\mathrm{g}}$ in 2006 and 2013, were comparable (2.81 and $2.38 \mathrm{~mm} \mathrm{yr}^{-1}$ respectively). As such, the $R_{\mathrm{n}}$ in 2006 was positive $\left(3.42 \mathrm{~mm} \mathrm{yr}^{-1}\right.$ ), having spatial extent similar to $R_{\mathrm{g}}$, while the $R_{\mathrm{n}}$ in 2013 was negative $\left(-1.29 \mathrm{~mm} \mathrm{yr}^{-1}\right)$ and restricted to similar locations as the $\mathrm{ET}_{\mathrm{g}}$. It can be concluded that the spatio-temporal CKB patterns of $R_{\mathrm{n}}$ depend mainly on spatio-temporal variability of rainfall, surface morphology, thickness of unsaturated zone, and vegetation type and density.

\section{Long-term temporal variability of water fluxes}

Large temporal variability of surface and subsurface water fluxes, both on a daily (Fig. 9) and yearly basis (Table 2), is observed. The CKB is characterized by erratic high-rainfall days (restricted to wet season), relatively low interception (Table 2), and erratic actual infiltration events, some of them even $>20 \mathrm{~mm}$ $\mathrm{d}^{-1}$ (Fig. 9a). However, the majority of that infiltration is removed from the unsaturated zone by generally large $\mathrm{ET}_{\mathrm{uz}}$, ranging from nearly zero in dry season when soil moisture is low or negligible, to even $5 \mathrm{~mm} \mathrm{~d}^{-1}$ during the wet season, so only a small portion of the infiltrated water arrives at the water table. This is because of: (1) the extremely large Kalahari PET, the largest in the hottest wet season; (2) the very thick unsaturated zone (with 'thirsty' Kalahari plants), which enhances water loss and restricts $R_{\mathrm{g}}$ to erratic daily episodes that in the 13 years of this study period, ranged from 0 up to only $0.13 \mathrm{~mm} \mathrm{~d}^{-1}$ in 2006 (Fig. 9b). The $\mathrm{ET}_{\mathrm{g}}$ is less temporally variable, varying from 0 to $0.02 \mathrm{~mm} \mathrm{~d}^{-1}$ in the similar manner as the water table, i.e. its peak is delayed several months with respect to the peak of the wet season rains. As such, the $\mathrm{ET}_{\mathrm{g}}$ peaks are also offset with respect to $\mathrm{ET}_{\mathrm{uz}}$ peaks, as the latter are mainly dependent on climatic factors, so rather matching the PET peaks.

The daily variability of $R_{\mathrm{n}}$ is presented in Fig. $9 \mathrm{~b}$. As defined by the difference between highly temporally variable $R_{\mathrm{g}}$ and moderately variable $\mathrm{ET}_{\mathrm{g}}$, the resultant $R_{\mathrm{n}}$-pattern follows the $R_{\mathrm{g}}$-pattern, being also highly temporally variable, ranging from -0.02 to $0.13 \mathrm{~mm} \mathrm{~d}^{-1}$. It is remarkable that on a yearly basis, there are only relatively short periods with $R_{\mathrm{n}}>0$, occurring not even every year. The exceptions are years 2006 and 2014 with above average annual precipitation (Table 2), when relatively large $R_{\mathrm{g}}$ was observed during many days, resulting in a positive annual $R_{\mathrm{n}}$. In the other 11 years, the $\mathrm{ET}_{\mathrm{g}}$ was dominant, so annual $R_{\mathrm{n}}<0$. The annual variability of $R_{\mathrm{n}}$ as well as of other water fluxes, is presented in Table 2 .

The nature of $R_{\mathrm{g}}$ and $R_{\mathrm{n}}$ dependence on precipitation is illustrated in Fig. 10, where it can be seen that below the $\sim 600-\mathrm{mm} \mathrm{yr}^{-1}$ annual rainfall threshold, there is nearly no change of $R_{\mathrm{g}}$ and $R_{\mathrm{n}}$. The substantial $R_{\mathrm{g}}$ and $R_{\mathrm{n}}$ increments take place only when annual rains exceed $600 \mathrm{~mm}$. Assuming a linear trend of rainfall-recharge in the years with the largest rainfall, as in Fig. 10, the backward-estimated annual $R_{\mathrm{g}}$ and $R_{\mathrm{n}}$ for the exceptionally wet year $1999 / 2000$, with $970-\mathrm{mm}$ rainfall (year not simulated), were $\sim 23$ and $16 \mathrm{~mm}$ respectively. The preceding assumption of linear trend is still quite modest, so most likely the recharge input was even larger.

The episodic nature of recharge events in the CKB is mainly attributed to erratic rainfall, thick unsaturated zone and very high PET as well as large $\mathrm{ET}_{\mathrm{uz}}$. Significant recharge events occur only in response to cumulated-in-time rainfall, consisting of a number of sequential above-average events. A similar observation was made also by Wanke et al. (2008) in a comparable environment.

\section{Sensitivity analysis}

The replenishment and therefore sustainability of groundwater resources largely depends on $R_{\mathrm{n}}$ (Lubczynski 2011, 2006); therefore, the sensitivity analysis in this study focused on testing $R_{\mathrm{g}}, \mathrm{ET}_{\mathrm{g}}$ and $\mathrm{EXF}_{\mathrm{gw}}$ as well as the resultant $R_{\mathrm{n}}$, all characterizing water exchange between the unsaturated and saturated zone. However, after preliminary tests, the $\mathrm{EXF}_{\mathrm{gw}}$ was excluded from further sensitivity analysis, as the $\mathrm{EXF}_{\mathrm{gw}}$ was negligible in all analysed years and in all tests, due to the generally deep water-table depth; thus, its sensitivity was also not relevant for the $R_{\mathrm{n}}$ estimate. Therefore, hereafter, the sensitivity analysis is shown only for $R_{\mathrm{g}}$ and $\mathrm{ET}_{\mathrm{g}}$ and for the resultant $R_{\mathrm{n}}$ (Fig. 11), all in the wettest year within the study period (hydrological year 2006). 

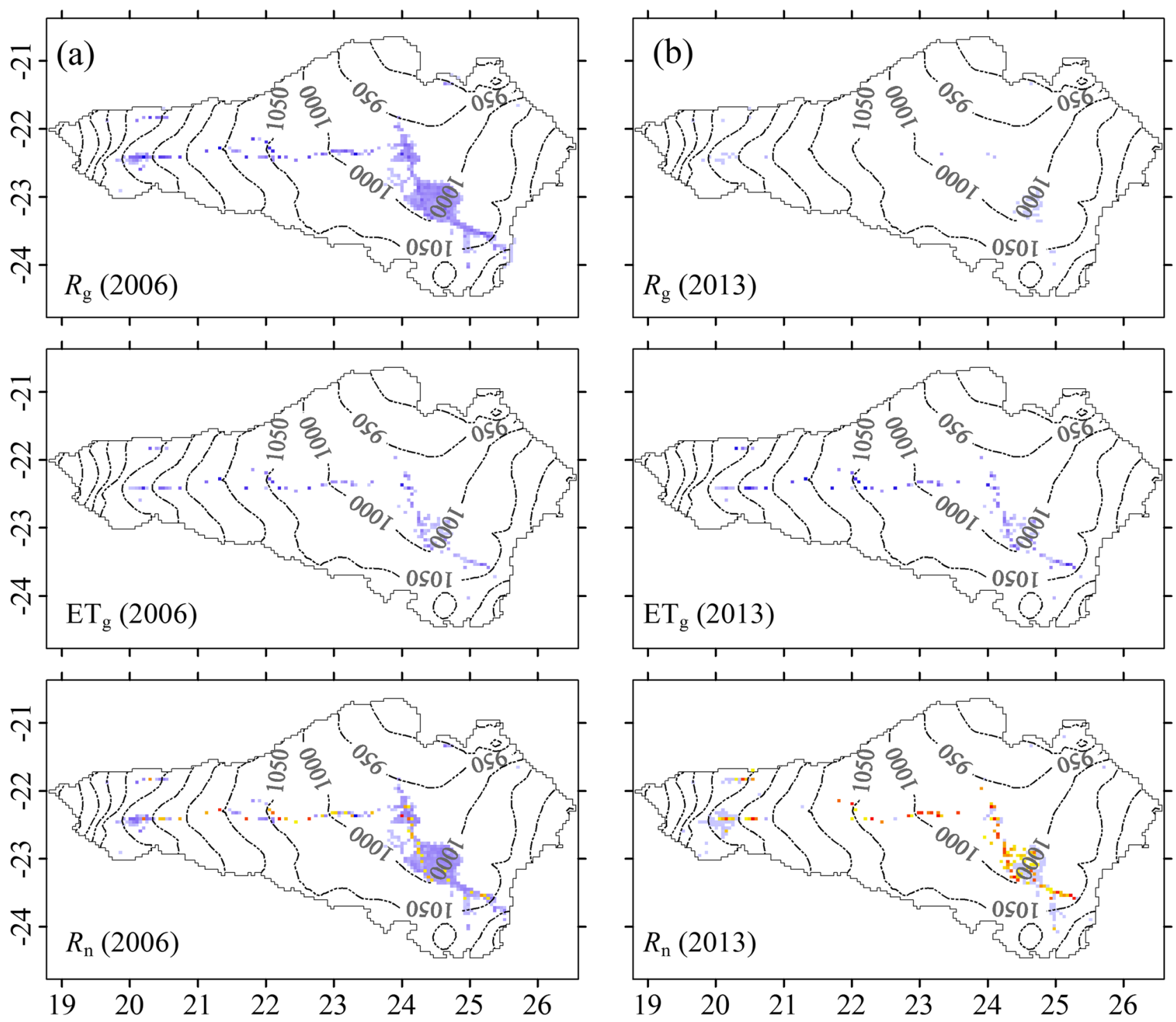

\section{Legend}

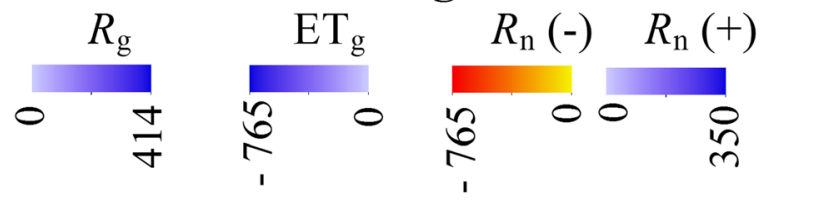

400 Kilometers
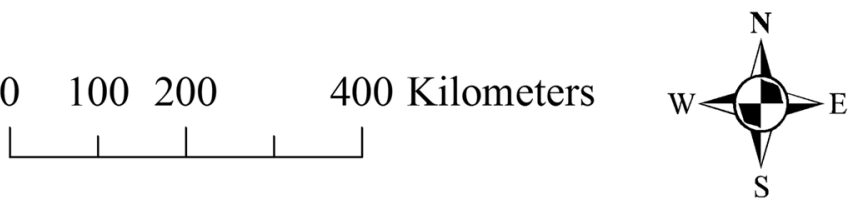

\section{Yearly averaged potentiometric surface}

Fig. 8 Spatial variability of gross recharge $\left(R_{\mathrm{g}}\right)$, groundwater evapotranspiration $\left(\mathrm{ET}_{\mathrm{g}}\right)$, and net recharge $\left(R_{\mathrm{n}}=R_{\mathrm{g}}-\mathrm{ET}_{\mathrm{g}}\right.$ as $\left.\mathrm{EXF}_{\mathrm{gw}}=0\right)$ for: $\mathbf{a} 2006 ; \mathbf{b}$ 2013 hydrological years

As the analysed year 2006 was relatively wet and the $R_{\mathrm{g}}$ was substantially larger than $\mathrm{ET}_{\mathrm{g}}$, therefore it had generally much larger effect upon the $R_{\mathrm{n}}$ than in other years while varying unsaturated zone parameters $\theta_{\mathrm{s}}, K_{\mathrm{v}}$ and EXTDP. In contrast, in dry years, the $R_{\mathrm{n}}$ was totally dependent on $\mathrm{ET}_{\mathrm{g}}$, as $R_{\mathrm{g}}$ was negligible. The $\mathrm{ET}_{\mathrm{g}}$ sensitivity to changes of $\theta_{\mathrm{s}}$ was generally low (Fig. 11), regardless of the $\mathrm{ET}_{\mathrm{g}}$ seasonal variability, driven mainly by the water-table fluctuation characterized by peaks delayed with respect to the occurrence of the wet seasons. The little peak of the $\mathrm{ET}_{\mathrm{g}}$ in $0.6 \theta_{\mathrm{s}}$ simulation at the end of April 2006, was likely attributed to the $\sim 1.5-2.0$-month delayed-water-table rise, in response to the $R_{\mathrm{g}}$ peak occurring around 1 March (Fig. 11). The $K_{\mathrm{v}}$ changes had very similar impact upon $\mathrm{ET}_{\mathrm{g}}$, having a similar little peak of $\mathrm{ET}_{\mathrm{g}}$ in April 2006 for $10-K_{\mathrm{v}}$ simulation, likely due to the same reason as in the $0.6-\theta_{\mathrm{s}}$ simulation. The sensitivity of the $\mathrm{ET}_{\mathrm{g}}$ to EXTDP 

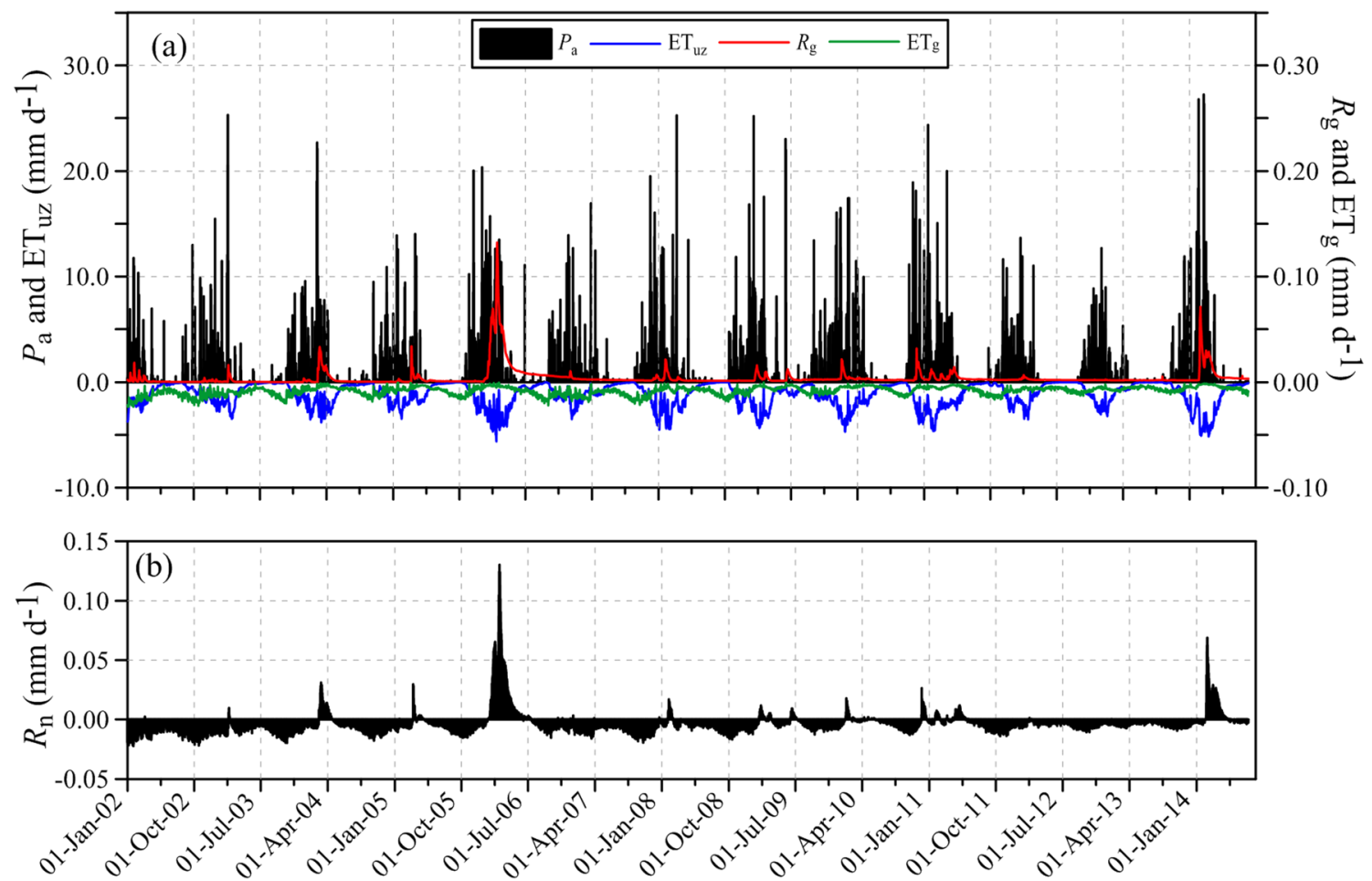

Fig. 9 Daily variability of different water balance components over the 13-year CKB simulation period: a actual infiltration $\left(P_{\mathrm{a}}\right)$, unsaturated zone evapotranspiration $\left(\mathrm{ET}_{\mathrm{uz}}\right)$, gross recharge $\left(R_{\mathrm{g}}\right)$ and groundwater evapotranspiration $\left(\mathrm{ET}_{\mathrm{g}}\right)$; b net recharge $\left(R_{\mathrm{n}}\right)$

was different compared to that of the other two parameters analysed. In general, the larger the $\mathrm{ET}_{\mathrm{g}}$ itself, the larger the differences were between different EXTDP simulations. It is remarkable that the $\mathrm{ET}_{\mathrm{g}}$ maxima and the largest differences between the three EXTDP simulations, were just before the wet season started, i.e. in October (Fig. 11c), with the largest $\mathrm{ET}_{\mathrm{g}}$ for 1.5-EXTDP simulation. After that peak, the differences between the three simulations gradually declined to be negligible already in February.

In the selected wet year 2006 (Fig. 11c), the $R_{\mathrm{g}}$ was sensitive to changes of all the three tested parameters $\left(\theta_{\mathrm{s}}, K_{\mathrm{v}}\right.$ and
EXTDP). The 0.6- $\theta_{\mathrm{s}}$ and $10-K_{\mathrm{v}}$ simulations, as well as the $1.4-\theta_{\mathrm{s}}$ and $0.1-K_{\mathrm{v}}$ simulations, had very similar effects upon $R_{\mathrm{g}}$, as both parameters, i.e. $\theta_{\mathrm{s}}$ and $K_{\mathrm{v}}$, similarly influence $K(\theta)$ in Eq. (1). What is remarkable in the presented $R_{\mathrm{g}}$ sensitivity patterns, is the peak around 1 March in response to wet-season accumulation of rain, with a clear sequence of peak occurrences, the fastest for the lowest $0.6 \theta_{\mathrm{s}}$ and for the largest $10 K_{\mathrm{v}}$, both, due to the largest $K(\theta)$. It is also remarkable that only the two simulations, i.e. $0.6 \theta_{\mathrm{s}}$ and $10 K_{\mathrm{v}}$, resulted in the delayed substantial $R_{\mathrm{g}}$ extending throughout the dry season, while in all the other $\theta_{\mathrm{s}}$ and $K_{\mathrm{v}}$ simulations, $R_{\mathrm{g}}$ converged to
Fig. 10 Cross-dependencies of yearly means of rainfall $(P)$ versus gross recharge $\left(R_{\mathrm{g}}\right)$ and net recharge $\left(R_{\mathrm{n}}\right)$

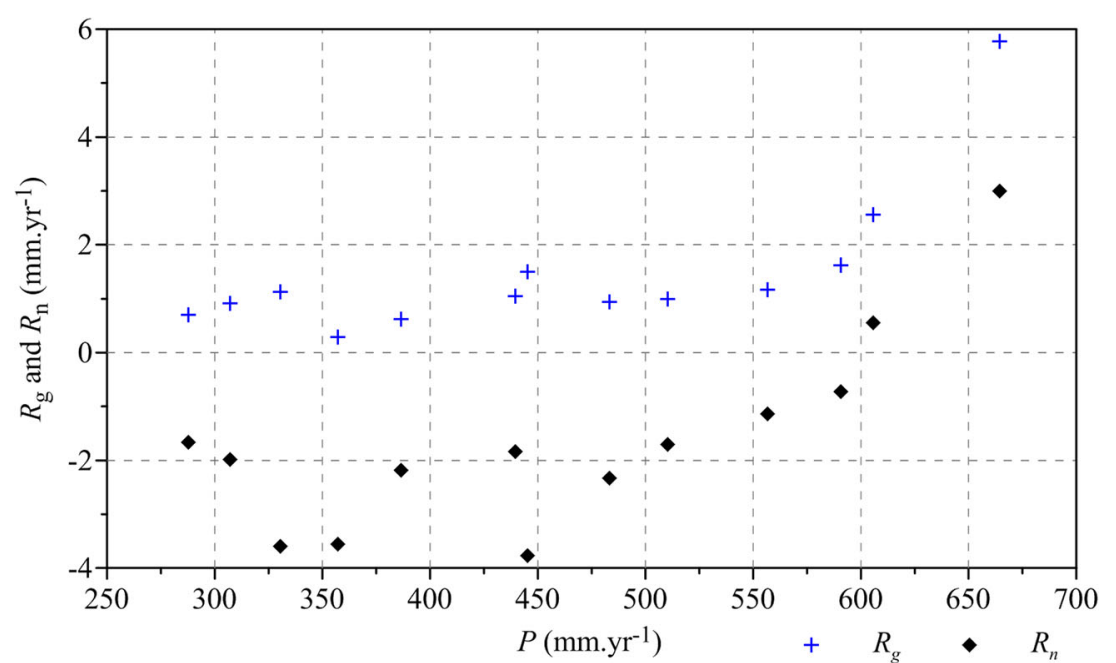


(a) $\theta_{\mathrm{s}}$

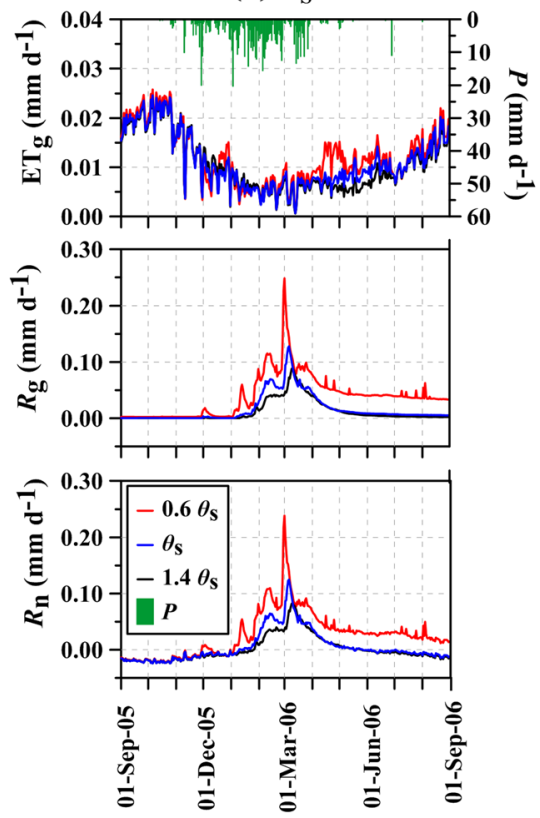

(b) $K_{\mathrm{V}}$

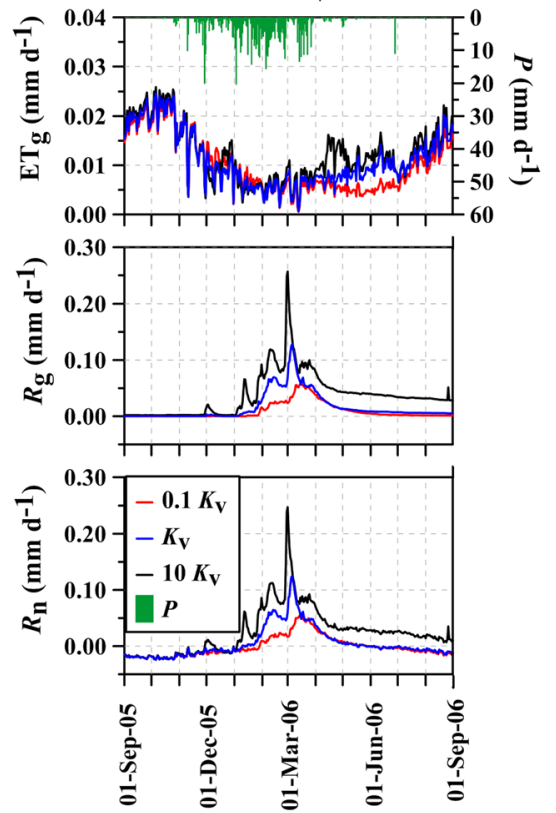

(c) EXTDP

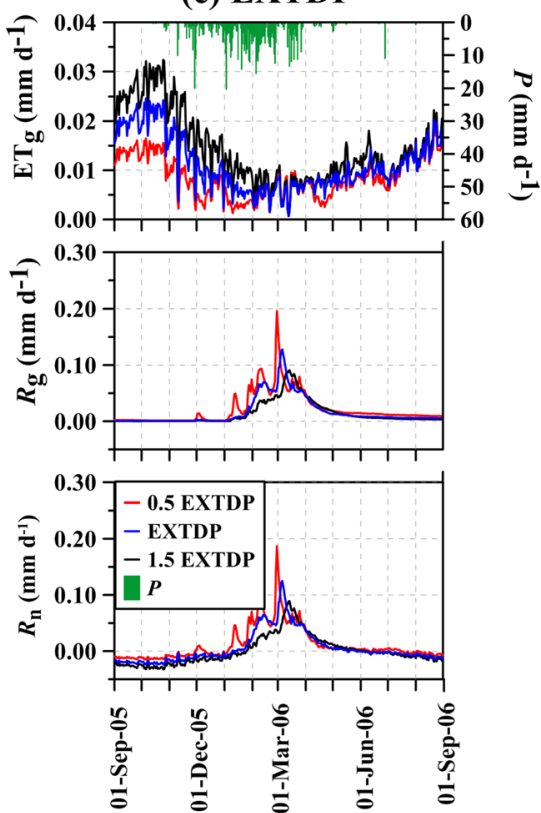

Fig. 11 Sensitivity analysis of: (1) groundwater evapotranspiration $\left(\mathrm{ET}_{\mathrm{g}}\right) ;(2)$ gross recharge $\left(R_{\mathrm{g}}\right)$; and (3) net recharge $\left(R_{\mathrm{n}}\right)$ in response to changes in the following model parameters: a soil saturated water content $\left(\theta_{\mathrm{s}}\right) ; \mathbf{b}$ UZF1 vertical hydraulic conductivity $\left(K_{\mathrm{v}}\right)$; c evapotranspiration extinction depth (EXTDP). The sensitivity analysis is presented for the wettest hydrological year, 2006 zero shortly after the wet season. In contrast, the nonzero $R_{\mathrm{g}}$ 'tail' extending throughout the dry season, was not present in any of the EXTDP simulations. Considering the sequential $R_{\mathrm{g}}$ peaks, they had similar timing and pattern as the $\theta_{\mathrm{s}}$ and $K_{\mathrm{v}}$ simulations. The largest $R_{\mathrm{g}}$ was attributed to the lowest EXTDP and the opposite, as the increment of EXTDP reduces the amount of water potentially available for $R_{\mathrm{g}}$. The $R_{\mathrm{n}}$ sensitivity, presented in Fig. 11, was very similar to the $R_{\mathrm{g}}$ because of the small impact of $\mathrm{ET}_{\mathrm{g}}$ in the wet year 2006 and generally negligible impact of $\mathrm{EXF}_{\mathrm{gw}}$.

\section{Experience of using remote sensing in data-scarce central Kalahari Basin}

The recent introduction of integrated hydrological models (IHMs) creates promising 'avenues' for novel remote sensing (RS) applications, not only in surface water but also in groundwater studies. This is because, in contrast to the standard standalone groundwater models, where driving forces, i.e. $R_{\mathrm{g}}$ and $\mathrm{ET}_{\mathrm{g}}$ were not quantifiable by RS, in the IHMs, the driving forces, i.e. rainfall and PET (Hassan et al. 2014), are well quantifiable by RS, while the $R_{\mathrm{g}}$ and $\mathrm{ET}_{\mathrm{g}}$ are estimated internally by IHMs based on land surface and unsaturated zone parameterization.

One of the main challenges of integrated hydrological modelling, particularly in arid and semi-arid areas characterized by large spatio-temporal variability of water-related fluxes, has been insufficient availability and quality of surface and subsurface input data. This study shows that RS can contribute to regional-scale IHMs, providing various types of readily available (downloadable) RS products, most importantly, spatiotemporally variable driving forces such as rainfall and PET.

With advancement in RS techniques, various satellite rainfall products at different spatial and temporal resolutions are now readily available and their spatial and temporal resolution increases. However, these rainfall products still need to be validated against in situ data to select the optimal product and eventually to remove the bias (Lekula et al. 2018b; Rahmawati and Lubczynski 2017). Also satellite-derived PET data are available as an RS product, although not as widely as rainfall and at much coarser spatial and temporal resolution. However, even with that limitation, the RS-based PET estimates are still useful because the PET is much less spatio-temporally variable than rainfall. Besides, if necessary (e.g. in local-scale assessments), with some effort, PET can be also defined at much better spatio-temporal resolution from raw multispectral RS data, as for example by Kim and Hogue (2008).

The remotely sensed earth observation from space cannot contribute to subsurface hydrostratigraphy of a model, except the upper model boundary, i.e. the topographic surface. The topographic surface, is nowadays derived by RS techniques, applying for example interferometry (e.g. Noferini et al. 2007; Wegmüller et al. 2009), LiDAR (e.g. Liu et al. 2005; Ma 2005) or analysis of stereoscopic images (e.g. Haala and Rothermel 2012; Xu, et al. 2010). These methods provide digital elevation models (DEMs) already at fine spatial resolution - in this study the SRTM 90-m DEM was downloaded from the CGIAR-CSI database (Jarvis et al. 2008). 
The UZF1 package of MODFLOW, which links surface input with groundwater, requires soil physical parameters and evapotranspiration extinction depth. The soil physical parameters can be estimated based on field sampling and literature sources but the challenge is how to spatially distribute them in the IHMs. For such a task as that, remotely sensed soil maps with quite detailed spatial distribution of different soil types is a solution. In this study, the spatial distribution of the soil physical parameters was defined using the "Soil Atlas of Africa" (Jones et al. 2013), largely based on remote sensing soil assessment, while parametric values were extracted from literature sources. The spatial distribution of the evapotranspiration extinction depth can be defined based on RS-based vegetation maps, provided the rooting depths of individual species can be realistically estimated from other sources. In this study, spatial distribution of evapotranspiration extinction depth was defined based on the RS-based, land use/land cover (LULC) maps (Loveland et al. 2000), while the rooting depth of plant species was defined based on Obakeng et al. (2007), Kleidon (2004) and Canadell et al. (1996).

Spatial and temporal resolution of the RS products can be an issue limiting their applicability as IHM input. If temporal resolution of most of the currently available RS products is already sufficient for typical daily input data requirements of most of the IHMs, the spatial resolution, (especially of RS rainfall) is still a limiting factor in their applicability to localscale IHMs, except maybe for some DEM products available at $<100 \mathrm{~m}$ resolution. Because of that limitation, the RS products are still mainly used in the regional-scale models, particularly those over areas with lack of or scarce monitoring networks such as the CKB. However, as the RS products continuously improve their spatial (and temporal) resolution, it is expected that shortly, they will also be more frequently applied in IHMs at the local-scale applications.

Considering the scarcity of fine spatial-resolution RS products, in the local scale IHMs, only tailor-made quantitative RS applications based on moderate, high- or very high-spatial resolution images can be utilized such as for example: (1) evapotranspiration mapping using Moderate Resolution Imaging Spectroradiometer (MODIS) with spatial resolution ranging from 0.5 to $1 \mathrm{~km}$ (Bastiaanssen et al. 1998a, b; Su 2002) or at highresolution using Landsat 8 imagery with spatial resolution of $100 \mathrm{~m}$ (Senay et al. 2016); (2) tree transpiration mapping using very high-resolution QuickBird or WorldView at $60-40 \mathrm{~cm}$ per pixel (Reyes-Acosta and Lubczynski 2013); (3) tree interception using QuickBird and WorldView at 60-40 $\mathrm{cm}$ per pixel (Hassan et al. 2017); the aforementioned tree transpiration and tree interception mapping methods require tree-scaling functions, which for nine dominant Kalahari tree species are presented by Lubczynski et al. (2017).

In RS applications at the local scale, unmanned aerial systems (drones) that can carry on-board multispectral cameras, can provide the required very high spatial resolution and are also cost effective (Colomina and Molina 2014). They are very convenient and efficient, so very promising in various environmental applications. However, drone data processing is still cumbersome and requires specialized knowledge; besides, in many countries use of drones requires a specific license, which can be difficult to obtain.

The reliability of models depends not only on driving forces and parameters, but also on state variables that represent model calibration reference. The RS techniques of earth observation from satellites, cannot detect the most commonly calibrated state variable, i.e. the water table, even at shallow water-table conditions. In that respect, the Gravity Recovery and Climate Experiment (GRACE) satellite, a joint mission launched by National Aeronautics Space Administration (NASA) and German Aerospace Center (DLR), was promising; this system detects changes in subsurface water storage, and thus also changes of aquifer water levels, through the analysis of gravity change (e.g. Leblanc et al. 2009; Rodell and Famiglietti 2001; Seoane et al. 2013; Yeh et al. 2006). However, GRACE assessment is done at a very coarse resolution of $\sim 400 \times 400 \mathrm{~km}$ (Sutanudjaja et al. 2014; Tapley et al. 2004), restricting its applicability to regional, or even continental-scale basins.

Another popular state variable applied in IHMs is river discharge. In contrast to groundwater levels, river discharges in ungauged catchments, can be approximated applying RS techniques (e.g Brakenridge et al. 2007; De Groeve 2010; Hirpa et al. 2013), although in this study such an assessment was not needed because in the CKB there are no flowing rivers.

With advancement in IHMs and improvement of accuracy of RS solutions of spatio-temporal soil moisture and actual evapotranspiration, these two variables can also be used as state variables in model calibration (e.g. Li et al. 2009; Lopez et al. 2017), although the currently available RS solutions of soil moisture and actual evapotranspiration still involve substantial error, particularly in dryland applications, where the error of RS quantification can be comparable or larger than the size of recorded water fluxes. Besides, the web-based products of soil moisture and actual evapotranspiration are still available only at a coarse resolution, which restricts their use in IHMs to large-scale regional assessments only, otherwise forcing researchers to process raw, higherresolution RS data, which, considering the typical, daily IHM data input requirement, is not only specialized, but also cumbersome and time consuming.

\section{Conclusions}

The increasingly used integrated hydrological models (IHMs) need spatio-temporally distributed surface-input data such as $P-I$ and PET (driving forces), unsaturated zone parameters, i.e. soil physical properties and evapotranspiration extinction depths, hydrogeological parameters and also state variables 
such as hydraulic heads or river discharges. Typically, such data on the ground are scarce or unavailable, particularly in remote areas of developing countries such as the Central Kalahari Basin (CKB). The alternative source is Remote Sensing (RS), although it does not provide all data types that is required by IHM input. The main objective of this study was to present the use of RS data in the setting of the IHM of a multi-layered aquifer system characterized by a very thick unsaturated zone such as the CKB and to provide its quantitative assessment. The key findings of this study are listed below:

1. The presented multi-layered CKB hydrogeological system has three aquifers-Lebung, Ecca and Ghanzi-whereby each aquifer receives diffuse recharge from rainfall through the top unconfined Kalahari Sand layer (either partially saturated or entirely unsaturated), while the Lebung and Ecca aquifers receive additional groundwater input from other overlying layers and small lateral inflows from outside the CKB. The flow patterns in all the aquifers are similar, with piezometric surfaces radially converging towards the central part of the basin from where all three aquifers discharge groundwater towards Makgadikgadi Pans. A considerable amount of groundwater is also discharged by groundwater evapotranspiration.

2. In semi-arid aquifer systems with a thick unsaturated zone such as the CKB, subsurface evapotranspiration is the dominant discharging water flux comparable with rainfall, while groundwater exfiltration is negligible because of the deep water table. As a consequence of the latter, gross recharge and groundwater evapotranspiration are comparable, so their yearly balance represented by the net recharge, is typically low or close to zero. Whether that balance is positive or negative, depends primarily on the annual rainfall amount and distribution, and secondarily on the water-table depth.

3. The groundwater resources in semi-arid aquifer systems with a thick unsaturated zone such as the CKB, are sustained only through recharge events of exceptionally wet years; however, within the 13-year simulation period, from 2002 to 2014, there was no such wet year. The wettest year was 2006 with annual rainfall $664 \mathrm{~mm}$, gross recharge $6.2 \mathrm{~mm}$ and net recharge $3.0 \mathrm{~mm}$; in the majority of other simulated years with lower rainfall, gross recharge was less than groundwater evapotranspiration, resulting in typically negative net recharge; the lowest, $-3.5 \mathrm{~mm}$, was in 2002 . The generally negative net recharge within the simulation period is the main reason for the observed declining trend of the water table and groundwater storage in the CKB.

4. Amount and temporal distribution of rainfall, surface morphology, thickness of the unsaturated zone and vegetation type/density, are primary determinants of the $R_{\mathrm{n}}$ spatial distribution in the CKB. The porosity, specific yield and vertical hydraulic conductivity of the unsaturated zone material are also important.

5. Advancement in integrated hydrological models (IHMs), coupling surface processes and groundwater flows, created new opportunities for using remote sensing (RS) techniques in hydrogeology. The RS can nowadays provide input data for IHMs at reasonable spatial and quite good temporal resolutions. Lots of such data is readily and freely-available as web-based products, which is particularly important in data-scarce areas with insufficient density of monitoring networks and/or inaccessible areas such as in the CKB. In this CKB-IHM study, the main RS contributions addressed rainfall, potential evapotranspiration, land cover and land use types, and terrain elevation, all acquired as web-based products.

6. As a follow up to this study it is recommended in the CKB to: (1) densify monitoring of water-table, to better control the IHM calibration process; (2) densify monitoring network of rainfall to improve bias correction of remotely sensed rainfall estimates; (3) investigate rooting depth of Kalahari plants, their water uptake and interception; (4) attempt to use the RS-based soil moisture, actual evapotranspiration and eventually GRACE satellite storage change as state variables of the IHM.

Acknowledgements Special thanks go to the Department of Water Affairs in Botswana, Botswana Geoscience Institution, Debswana Diamond Mining Company and Directorate of Water Resources Management in Namibia, for providing the geological and hydrogeological data that made this study possible. Dr. Richard G Niswonger and Dr. Richard B Winston from USGS are greatly acknowledged for their interactive discussion about the UZF1 package and two anonymous reviewers for their constructive critics that substantially contributed to the improvement of this paper. Free online databases for geological data for Namibia used in this study are also acknowledged.

Funding information This study is part of the first author's $\mathrm{PhD}$ research, which was supported financially by the Botswana Government through Botswana International University of Science and Technology.

Open Access This article is distributed under the terms of the Creative Commons Attribution 4.0 International License (http:// creativecommons.org/licenses/by/4.0/), which permits unrestricted use, distribution, and reproduction in any medium, provided you give appropriate credit to the original author(s) and the source, provide a link to the Creative Commons license, and indicate if changes were made.

\section{References}

Alaghmand S, Beecham S, Hassanli A (2014) Impacts of vegetation cover on surface-groundwater flows and solute interactions in a semi-arid saline floodplain: a case study of the lower Murray River, Australia. Environ Proc 1:59-71. https://doi.org/10.1007/ s40710-014-0003-0

Allen RG, Pereira LS, Raes D, Smith M (1998) Crop evapotranspiration: guidelines for computing crop water requirements. FAO Irrigation and Drainage Paper 56, FAO, Rome, D05109 
Anderson MP, Woessner WW, Hunt RJ (2015) Applied groundwater modeling: simulation of flow and advective transport, 2nd edn. Elsevier, San Diego, CA

Ashby SF, Falgout RD (1996) A parallel multigrid preconditioned conjugate gradient algorithm for groundwater flow simulations. Nucl Sci Eng 124:145-159. https://doi.org/10.13182/nse96-a24230

Awan UK, Tischbein B, Martius C (2013) Combining hydrological modeling and GIS approaches to determine the spatial distribution of groundwater recharge in an arid irrigation scheme. Irrig Sci 31: 793-806. https://doi.org/10.1007/s00271-012-0362-0

Bailey RT, Morway ED, Niswonger RG, Gates TK (2013) Modeling variably saturated multispecies reactive groundwater solute transport with MODFLOW-UZF and RT3D. Ground Water 51:752761. https://doi.org/10.1111/j.1745-6584.2012.01009.x

Balugani E, Lubczynski MW, Metselaar K (2016) A framework for sourcing of evaporation between saturated and unsaturated zone in bare soil condition. Hydrol Sci J 61:1981-1995. https://doi.org/10. 1080/02626667.2014.966718

Bastiaanssen WGM, Menenti M, Feddes RA, Holtslag AAM (1998a) A remote sensing surface energy balance algorithm for land (SEBAL): 1. formulation. J Hydrol 212:198-212. https://doi.org/10.1016/ s0022-1694(98)00253-4

Bastiaanssen WGM, Pelgrum H, Wang J, Ma Y, Moreno JF, Roerink GJ, van der Wal T (1998b) A remote sensing surface energy balance algorithm for land (SEBAL): 2. validation. J Hydrol 212:213-229. https://doi.org/10.1016/s0022-1694(98)00254-6

Batisani N, Yarnal B (2010) Rainfall variability and trends in semi-arid Botswana: implications for climate change adaptation policy. Appl Geogr 30:483-489. https://doi.org/10.1016/j.apgeog.2009.10.007

Bauer P, Gumbricht T, Kinzelbach W (2006) A regional coupled surface water/groundwater model of the Okavango Delta, Botswana. Water Resour Res 42:W04403. https://doi.org/10.1029/2005WR004234

Bhalotra YPR (1987) Climate of Botswana Part II: elements of climate. Department of Meteorological Services, Gaborone, Botswana

Brakenridge GR, Nghiem SV, Anderson E, Mic R (2007) Orbital microwave measurement of river discharge and ice status. Water Resour Res 43. https://doi.org/10.1029/2006WR005238

Brooks RH, Corey AT (1966) Properties of porous media affecting fluid flow. J Irrig Drain Div 92:61-90

Brunner P, Simmons CT (2012) HydroGeoSphere: a fully integrated, physically based hydrological model. Ground Water 50:170-176. https://doi.org/10.1111/j.1745-6584.2011.00882.x

Brunner P, Bauer P, Eugster M, Kinzelbach W (2004) Using remote sensing to regionalize local precipitation recharge rates obtained from the chloride method. J Hydrol 294:241-250. https://doi.org/ 10.1016/j.jhydrol.2004.02.023

Brunner P, Hendricks Franssen HJ, Kgotlhang L, Bauer-Gottwein P, Kinzelbach W (2007) How can remote sensing contribute in groundwater modeling? Hydrogeol J 15:5-18. https://doi.org/10. 1007/s10040-006-0127-z

Canadell J, Jackson RB, Ehleringer JR, Mooney HA, Sala OE, Schulze ED (1996) Maximum rooting depth of vegetation types at the global scale. Oecologia 108:583-595. https://doi.org/10.1007/bf00329030

Carsel RF, Parrish RS (1988) Developing joint probability-distributions of soil-water retention characteristics. Water Resour Res 24:755769. https://doi.org/10.1029/WR024i005p00755

Choudhury BJ (1997) Global pattern of potential evaporation calculated from the Penman-Monteith equation using satellite and assimilated data. Remote Sens Environ 61:64-81. https://doi.org/10.1016/ S0034-4257(96)00241-6

Coelho VHR, Montenegro S, Almeida CN, Silva BB, Oliveira LM, Gusmao ACV, Freitas ES, Montenegro AAA (2017) Alluvial groundwater recharge estimation in semi-arid environment using remotely sensed data. J Hydrol 548:1-15. https://doi.org/10.1016/j. jhydrol.2017.02.054
Colomina I, Molina P (2014) Unmanned aerial systems for photogrammetry and remote sensing: a review. ISPRS J Photogramm Remote Sens 92:79-97. https://doi.org/10.1016/j.isprsjprs.2014.02.013

Dai Y, Zeng X, Dickinson RE, Baker I, Bonan GB, Bosilovich MG, Denning AS, Dirmeyer PA, Houser PR, Niu G (2003) The common land model. Bull Am Meteorol Soc 84:1013-1024

Danish Hydraulic Institute (1998) MIKE SHE water movement: user's guide and technical reference manual. Danish Hydraulic Institute, Hørsholm, Denmark

Davison JH, Hwang HT, Sudicky EA, Mallia DV, Lin JC (2018) Full coupling between the atmosphere, surface, and subsurface for integrated hydrologic simulation. J Adv Model Earth Syst 10:43-53. https://doi.org/10.1002/2017ms001052

De Groeve T (2010) Flood monitoring and mapping using passive microwave remote sensing in Namibia. Geomat Nat Haz Risk 1:19-35

de Vries JJ (1984) Holocene depletion and active recharge of the Kalahari groundwaters: a review and an indicative model. J Hydrol 70:221232. https://doi.org/10.1016/0022-1694(84)90123-9

de Vries JJ, Selaolo ET, Beekman HE (2000) Groundwater recharge in the Kalahari, with reference to paleo-hydrologic conditions. J Hydrol 238:110-123. https://doi.org/10.1016/s0022-1694(00) 00325-5

Doherty JE, Hunt RJ (2010) Approaches to highly parameterized inversion: a guide to using PEST for groundwater-model calibration. US Geol Surv Sci Invest Rep 2010-5211

Domenico PA, Schwartz FW (1998) Physical and chemical hydrogeology, 2nd edn. Wiley, New York

Downer CW, Ogden FL (2004) Appropriate vertical discretization of Richards' equation for two-dimensional watershed-scale modelling. Hydrol Process 18:1-22. https://doi.org/10.1002/hyp.1306

El-Zehairy AA, Lubczynski MW, Gurwin J (2018) Interactions of artificial lakes with groundwater applying an integrated MODFLOW solution. Hydrogeol J 26:109-132. https://doi.org/10.1007/s10040-017-1641-x

Gong H, Pan Y, Xu Y (2012) Spatio-temporal variation of groundwater recharge in response to variability in precipitation, land use and soil in Yanqing Basin, Beijing, China. Hydrogeol J 20:1331-1340. https://doi.org/10.1007/s10040-012-0883-x

Haala N, Rothermel M (2012) Dense multi-stereo matching for high quality digital elevation models. Photogramm Fernerkund Geoinf 2012(4):331-343. https://doi.org/10.1127/1432-8364/2012/0121

Harbaugh AW (1990) A computer program for calculating subregional water budgets using results from the US Geological Survey modular three-dimensional finite-difference ground-water flow model. US Geological Survey, Reston, VA

Harter T, Hopmans JW (2004) Role of vadose zone flow processes in regional scale hydrology: review, opportunities and challenges. In: Feddes R, De Rooij GH, Van Dam JC (eds) Unsaturated zone modeling: progress, challenges and applications. UR Frontis Series, Wageningen, Springer, Heidelberg, Germany, pp 179-208

Hassan SMT, Lubczynski MW, Niswonger RG, Su Z (2014) Surfacegroundwater interactions in hard rocks in Sardon catchment of western Spain: an integrated modeling approach. J Hydrol 517:390-410. https://doi.org/10.1016/j.jhydrol.2014.05.026

Hassan SMT, Ghimire CP, Lubczynski MW (2017) Remote sensing upscaling of interception loss from isolated oaks: Sardon catchment case study, Spain. J Hydrol 555:489-505. https://doi.org/10.1016/j. jhydrol.2017.08.016

Hay LE, Markstrom SL, Ward-Garrison C (2010) Watershed-scale response to climate change through the twenty-first century for selected basins across the United States. Earth Interact 15:1-37. https:// doi.org/10.1175/2010EI370.1

Henry CM, Allen DM, Huang J (2011) Groundwater storage variability and annual recharge using well-hydrograph and GRACE satellite data. Hydrogeol J 19:741-755. https://doi.org/10.1007/s10040011-0724-3 
Herman A, Kumar VB, Arkin PA, Kousky JV (1997) Objectively determined 10-day African rainfall estimates created for famine early warning systems. Int J Remote Sens 18:2147-2159. https://doi. org/10.1080/014311697217800

Hill MC, Tiedeman CR (2006) Effective groundwater model calibration: with analysis of data, sensitivities, predictions, and uncertainty. Wiley, Hoboken, NJ

Hirpa FA, Hopson TM, De Groeve T, Brakenridge GR, Gebremichael M, Restrepo PJ (2013) Upstream satellite remote sensing for river discharge forecasting: application to major rivers in South Asia. Remote Sens Environ 131:140-151. https://doi.org/10.1016/j.rse. 2012.11.013

Hsieh PA, Freckleton JR (1993) Documentation of a computer program to simulate horizontal-flow barriers using the US Geological Survey's modular three-dimensional finite-difference ground-water flow model. US Geol Surv Open-File Rep 92-477

Huntington JL, Niswonger RG (2012) Role of surface-water and groundwater interactions on projected summertime streamflow in snow dominated regions: an integrated modeling approach. Water Resour Res 48:W11524. https://doi.org/10.1029/2012WR012319

Jarvis A, Reuter HI, Nelson A, Guevara E (2008) Hole-filled SRTM for the globe, version 4. available from the CGIAR-CSI SRTM $90 \mathrm{~m}$ Database. http://srtm.csi.cgiar.org. Accessed December 2018

Jasrotia AS, Kumar R, Saraf AK (2007) Delineation of groundwater recharge sites using integrated remote sensing and GIS in Jammu district, India. Int J Remote Sens 28:5019-5036. https://doi.org/10. 1080/01431160701264276

Jones A, Breuning-Madsen H, Brossard M, Dampha A, Deckers J, Dewitte O, Gallali T, Hallett S, Jones R, Kilasara M (2013) Soil Atlas of Africa. European Commission, Publications Office of the European Union, Brussels, 176 pp. https://doi.org/10.2788/52319

Joshua WD (1991) Physical properties of the soils of Botswana. Field document 33. Gov. of Botswana, Gaborone

Khalaf A, Donoghue D (2012) Estimating recharge distribution using remote sensing: a case study from the West Bank. J Hydrol 414 415:354-363. https://doi.org/10.1016/j.jhydrol.2011.11.006

Kim J, Hogue TS (2008) Evaluation of a MODIS-based potential evapotranspiration product at the point scale. J Hydrometeorol 9:444-460. https://doi.org/10.1175/2007jhm902.1

Kleidon A (2004) Global datasets of rooting zone depth inferred from inverse methods. J Clim 17:2714-2722. https://doi.org/10.1175/ 1520-0442(2004)017<2714: gdorzd >2.0.co;2

Kollet SJ, Maxwell RM (2006) Integrated surface-groundwater flow modeling: a free-surface overland flow boundary condition in a parallel groundwater flow model. Adv Water Resour 29:945-958. https://doi.org/10.1016/j.advwatres.2005.08.006

Le Maitre DC, Scott DF, Colvin C (1999) A review of information on interactions between vegetation and groundwater. Water SA 25: $137-152$

Leblanc M, Favreau G, Tweed S, Leduc C, Razack M, Mofor L (2007) Remote sensing for groundwater modelling in large semiarid areas: Lake Chad Basin, Africa. Hydrogeol J 15:97-100. https://doi.org/ 10.1007/s10040-006-0126-0

Leblanc MJ, Tregoning P, Ramillien G, Tweed SO, Fakes A (2009) Basin-scale, integrated observations of the early 21 st century multiyear drought in southeast Australia. Water Resour Res 45. https:// doi.org/10.1029/2008WR007333

Lekula M, Lubczynski MW, Shemang EM (2018a) Hydrogeological conceptual model of large and complex sedimentary aquifer systems: central Kalahari Basin (Botswana). Phys Chem Earth A/B/C. https://doi.org/10.1016/j.pce.2018.05.006

Lekula M, Lubczynski MW, Shemang EM, Verhoef W (2018b) Validation of satellite-based rainfall in Kalahari. Phys Chem Earth A/B/C 105:85-97. https://doi.org/10.1016/j.pce.2018.02.010

Li HT, Brunner P, Kinzelbach W, Li WP, Dong XG (2009) Calibration of a groundwater model using pattern information from remote sensing data. J Hydrol 377:120-130. https://doi.org/10.1016/j.jhydrol.2009. 08.012

Liu X, Peterson J, Zhang Z (2005) High-resolution DEM generated from LiDAR data for water resource management. In: Zerger A, Argent RM (eds) MODSIM 2005: International Congress on Modelling and Simulation-Advances and Applications for Management and Decision Making. Modelling and Simulation Society of Australia and New Zealand, Canberra, Australia, pp 1402-1408

Lopez PL, Sutanudjaja EH, Schellekens J, Sterk G, Bierkens MFP (2017) Calibration of a large-scale hydrological model using satellite-based soil moisture and evapotranspiration products. Hydrol Earth Syst Sci 21:3125-3144. https://doi.org/10.5194/hess-21-3125-2017

Loveland TR, Reed BC, Brown JF, Ohlen DO, Zhu Z, Yang L, Merchant JW (2000) Development of a global land cover characteristics database and IGBP DISCover from $1 \mathrm{~km}$ AVHRR data. Int J Remote Sens 21:1303-1330. https://doi.org/10.1080/014311600210191

Lubczynski MW (2000) Groundwater evapotranspiration underestimated component of the groundwater balance in a semiarid environment: Serowe case, Botswana. In: Groundwater: past achievements and future challenges. Balkema, Rotterdam, The Netherlands

Lubczynski MW (2006) Groundwater fluxes in arid and semi-arid environments. In: Baba A, Howard KWF, Gunduz O (eds) Groundwater and ecosystems. NATO Science Series IV Earth and Environmental Sciences, Springer, Heidelberg, Germany, pp 225-236

Lubczynski MW (2009) The hydrogeological role of trees in waterlimited environments. Hydrogeol J 17:247-259. https://doi.org/10. 1007/s10040-008-0357-3

Lubczynski MW (2011) Groundwater evapotranspiration: underestimated role of tree transpiration and bare soil evaporation in groundwater balances of dry lands. In: Baba A, Gunduz O, Friedel MJ, Tayfur G, Howard KWF, Chambel A (eds) Climate change and its effects on water resources: issues of national and global security. NATO Science for Peace and Security Series C: Environmental Security, Springer, Heidelberg, Germany, pp 183190

Lubczynski MW, Chavarro-Rincon DC, Rossiter DG (2017) Conductive sapwood area prediction from stem and canopy areas - allometric equations of Kalahari trees, Botswana. Ecohydrology, 10(6):e1856. https://doi.org/10.1002/eco.1856

Ma R (2005) DEM generation and building detection from Lidar data. Photogramm Eng Remote Sens 71:847-854. https://doi.org/10. 14358/PERS.71.7.847

Ma L, He C, Bian H, Sheng L (2016) MIKE SHE modeling of ecohydrological processes: merits, applications, and challenges. Ecol Eng 96:137-149. https://doi.org/10.1016/j.ecoleng.2016.01. 008

Markstrom SL, Niswonger RG, Regan RS, Prudic DE, Barlow PM (2008) GSFLOW: coupled ground-water and surface-water flow model based on the integration of the Precipitation-Runoff Modeling System (PRMS) and the Modular Ground-Water Flow Model (MODFLOW-2005). US Geological Survey, Reston, VA

Masterson JP, Pope JP, Fienen MN, Monti Jr J, Nardi MR, Finkelstein JS (2016) Documentation of a groundwater flow model developed to assess groundwater availability in the northern Atlantic coastal plain aquifer system from Long Island, New York, to North Carolina. US Geol Surv Sci Invest Rep 2016-5076

Maxwell RM, Miller NL (2005) Development of a coupled land surface and groundwater model. J Hydrometeorol 6:233-247. https://doi. org $/ 10.1175 / \mathrm{jhm} 422.1$

McDonald MG, Harbaugh AW (1988) A modular three-dimensional finite-difference ground-water flow model. US Geol Surv Open File Rep 83-875

Meijerink AM, Bannert D, Batelaan O, Lubczynski M, Pointet T (2007) Remote sensing applications to groundwater. UNESCO, Paris 
Miralles DG, Gash JH, Holmes TRH, de Jeu RAM, Dolman AJ (2010) Global canopy interception from satellite observations. J Geophys Res Atmos 115. https://doi.org/10.1029/2009JD013530

Morway ED, Niswonger RG, Langevin CD, Bailey RT, Healy RW (2013) Modeling variably saturated subsurface solute transport with MODFLOW-UZF and MT3DMS. Ground Water 51:237-251. https://doi.org/10.1111/j.1745-6584.2012.00971.x

Niswonger RG, Prudic DE (2004) Modeling variably saturated flow using kinematic waves in MODFLOW. In: Hogan JF, Phillips FM, Scanlon BR (eds) Groundwater recharge in a desert environment: the southwestern United States water science and application. American Geophysical Union, Washington, DC, pp 101-112

Niswonger RG, Prudic DE, Regan RS (2006) Documentation of the unsaturated-zone flow (UZF1) package for modeling unsaturated flow between the land surface and the water table with MODFLOW-2005, chap 19. In: Richard G (ed) Modeling techniques. US Geological Survey, Reston, VA

Niswonger RG, Panday S, Ibaraki M (2011) MODFLOW-NWT, a Newton formulation for MODFLOW-2005. US Geological Survey. https://water.usgs.gov/ogw/modflow-nwt/. Accessed December 2018

Niu GY, Yang ZL, Mitchell KE, Chen F, Ek MB, Barlage M, Kumar A, Manning K, Niyogi D, Rosero E, Tewari M, Xia YL (2011) The community Noah land surface model with multiparameterization options (Noah-MP): 1. model description and evaluation with local-scale measurements. J Geophys Res-Atmos 116. https://doi. org/10.1029/2010jd015139

Niu GY, Paniconi C, Troch PA, Scott RL, Durcik M, Zeng XB, Huxman T, Goodrich DC (2014) An integrated modelling framework of catchment-scale ecohydrological processes: 1 . model description and tests over an energy-limited watershed. Ecohydrology 7:427439. https://doi.org/10.1002/eco.1362

Noferini L, Pieraccini M, Mecatti D, Macaluso G, Luzi G, Atzeni C (2007) DEM by ground-based SAR interferometry. IEEE Geosci Remote Sens Lett 4:659-663. https://doi.org/10.1109/LGRS.2007. 905118

Obakeng OT, de Vries JJ, Lubczynski MW (2007) Soil moisture dynamics and evapotranspiration at the fringe of the Botswana Kalahari, with emphasis on deep rooting vegetation. PhD Thesis, Vrije Universiteit Amsterdam, The Netherlands

Panday S, Huyakorn PS (2004) A fully coupled physically-based spatially-distributed model for evaluating surface/subsurface flow. Adv Water Resour 27:361-382. https://doi.org/10.1016/j.advwatres. 2004.02.016

Paniconi C, Marrocu M, Putti M, Verbunt M (2003) Newtonian nudging for a Richards' equation-based distributed hydrological model. Adv Water Resour 26:161-178. https://doi.org/10.1016/s0309-1708(02) 00099-4

Rahmawati N, Lubczynski MW (2017) Validation of satellite daily rainfall estimates in complex terrain of Bali Island, Indonesia. Theor Appl Climatol. https://doi.org/10.1007/s00704-017-2290-7

Refsgaard JCJJC (2010) Système Hydrologique Européen (SHE): review and perspectives after 30 years development in distributed physically-based hydrological modelling. Hydrol Res 41:355-377

Reyes-Acosta JL, Lubczynski MW (2013) Mapping dry-season tree transpiration of an oak woodland at the catchment scale, using objectattributes derived from satellite imagery and sap flow measurements. Agric For Meteorol 174:184-201. https://doi.org/10.1016/j. agrformet.2013.02.012

Rihani JF, Maxwell RM, Chow FK (2010) Coupling groundwater and land surface processes: idealized simulations to identify effects of terrain and subsurface heterogeneity on land surface energy fluxes. Water Resour Res 46. https://doi.org/10.1029/2010wr009111

RockWare (2017) Earth science and GIS Software. Available at https:// www.rockware.com/. Accessed December 2018
Rodell M, Famiglietti JS (2001) An analysis of terrestrial water storage variations in Illinois with implications for the gravity recovery and climate experiment (GRACE). Water Resour Res 37:1327-1339. https://doi.org/10.1029/2000wr900306

Rodell M, Famiglietti JS (2002) The potential for satellite-based monitoring of groundwater storage changes using GRACE: the High Plains aquifer, central US. J Hydrol 263:245-256. https://doi.org/ 10.1016/S0022-1694(02)00060-4

Rodell M, Chen JL, Kato H, Famiglietti JS, Nigro J, Wilson CR (2007) Estimating groundwater storage changes in the Mississippi River basin (USA) using GRACE. Hydrogeol J 15:159-166. https://doi. org/10.1007/s10040-006-0103-7

Sarma D, Xu Y (2017) The recharge process in alluvial strip aquifers in arid Namibia and implication for artificial recharge. Hydrogeol $\mathrm{J} 25$ : 123-134. https://doi.org/10.1007/s10040-016-1474-z

Schmugge TJ, Kustas WP, Ritchie JC, Jackson TJ, Rango A (2002) Remote sensing in hydrology. Adv Water Resour 25:1367-1385. https://doi.org/10.1016/s0309-1708(02)00065-9

Senay GB, Friedrichs M, Singh RK, Velpuri NM (2016) Evaluating Landsat 8 evapotranspiration for water use mapping in the Colorado River basin. Remote Sens Environ 185:171-185. https:// doi.org/10.1016/j.rse.2015.12.043

Seoane L, Ramillien G, Frappart F, Leblanc M (2013) Regional GRACEbased estimates of water mass variations over Australia: validation and interpretation. Hydrol Earth Syst Sci 17:4925-4939. https://doi. org $/ 10.5194 /$ hess-17-4925-2013

Sheikh V, Visser S, Stroosnijder L (2009) A simple model to predict soil moisture: bridging event and continuous hydrological (BEACH) modelling. Environ Model Softw 24:542-556. https://doi.org/10. 1016/j.envsoft.2008.10.005

Shuttleworth WJ (1993) Evaporation. In: Maidment DR (ed) Handbook of hydrology. McGraw-Hill, New York, pp 4.1-4.53

Šimůnek J, Van Genuchten MT, Šejna M (2012) The HYDRUS software package for simulating two-and three-dimensional movement of water, heat, and multiple solutes in variably-saturated media. PC Progress, Prague, Czech Republic, 258 pp

SMEC, EHES (2006) Botswana National Water Master Plan Review Unpublished report of Snowy Mountains Engineering Corporation (SMEC) and EHES Consulting Engineers, Department of Water Affairs, Gaborone, Botswana, $311 \mathrm{pp}$

Smith RA (1984) The Lithostratigraphy of the Karoo Supergroup in Botswana. Department of Geological Survey, Gaborone, Botswana

Smith RE, Hebbert RHB (1983) Mathematical simulation of interdependent surface and subsurface hydrologic processes. Water Resour Res 19:987-1001. https://doi.org/10.1029/WR019i004p00987

Su Z (2002) The surface energy balance system (SEBS) for estimation of turbulent heat fluxes. Hydrol Earth Syst Sci 6:85-99. https://doi.org/ 10.5194/hess-6-85-2002

Surfleet CG, Tullos D (2013) Uncertainty in hydrologic modelling for estimating hydrologic response due to climate change (Santiam River, Oregon). Hydrol Process 27:3560-3576. https://doi.org/10. 1002/hyp.9485

Surfleet CG, Tullos D, Chang H, Jung IW (2012) Selection of hydrologic modeling approaches for climate change assessment: a comparison of model scale and structures. J Hydrol 464:233-248. https://doi. org/10.1016/j.jhydrol.2012.07.012

Sutanudjaja EH, van Beek LPH, de Jong SM, van Geer FC, Bierkens MFP (2014) Calibrating a large-extent high-resolution coupled groundwater-land surface model using soil moisture and discharge data. Water Resour Res 50:687-705. https://doi.org/10.1002/ 2013WR013807

Taniguchi M, Yamamoto K, Sarukkalige PR (2011) Groundwater resources assessment based on satellite GRACE and hydrogeology in Western Australia. In: Hafeez M, VanDeGiesen N, Bardsley E, Seyler F, Pail R, Taniguchi M (eds) Grace: remote sensing and ground-based methods in multi-scale hydrology. IAHS Series of 
Proceedings and Reports, book 343, IAHS, Wallingford, UK, pp 3 8

Tapley BD, Bettadpur S, Watkins M, Reigber C (2004) The gravity recovery and climate experiment: mission overview and early results. Geophys Res Lett 31. https://doi.org/10.1029/2004GL019920

Therrien R (1992) Three-dimensional analysis of variably-saturated flow and solute transport in discretely-fractured porous media. $\mathrm{PhD}$ Thesis, University of Waterloo, Canada

Therrien R, McLaren R, Sudicky E, Panday S (2006) HydroGeoSphere. Groundwater Simul. Group. University of Waterloo, Canada. Link to software: http://hydrogeosphere.org/. Accessed December 2018

USGS (2007) FEWSNET data downloads. https://earlywarning.usgs. gov/fews/datadownloads. Accessed 6 March 2017

Wanke H, Dunkeloh A, Udluft P (2008) Groundwater recharge assessment for the Kalahari catchment of north-eastern Namibia and north-western Botswana with a regional-scale water balance model. Water Resour Manag 22:1143-1158. https://doi.org/10.1007/ s11269-007-9217-5

Wegmüller U, Santoro M, Werner C, Strozzi T, Wiesmann A, Lengert W (2009) DEM generation using ERS-ENVISAT interferometry. J Appl Geophys 69:51-58. https://doi.org/10.1016/j.jappgeo.2009.04.002

Werger MJ, van Bruggen AC (1978) Biogeography and ecology of southern Africa. Springer, Berlin

Winston R (2009) ModelMuse: a graphical user interface for MODFLOW-2005 and PHAST. US Geological Survey
Techniques and Methods 6-A29. US Geological Survey. Available online at http://pubsusgs.gov/tm/tm6A29. Accessed December 2018

Xu C, Wei M, Griffiths S, Mercer B, Abdoullaev R, Isprs (2010) Hybrid DEM generation and evaluation from spaceborne radargrammetric and optical stereoscopic DEMS. 2010 Canadian Geomatics Conference and Symposium of Commission I, ISPRS Convergence in Geomatics: Shaping Canada's Competitive Landscape. Int. Archives of the Photogrammetry Remote Sensing and Spatial Information Sciences, Leibniz Universität Hannover, Germany

Yeh G, Cheng H, Huang G, Zhang F, Lin H, Edris E, Richards D (2003) A numerical model of flow, heat transfer, and salinity, sediment, and water quality transport in watershed systems of $1 \mathrm{D}$ stream-river network, 2D overland regime, and 3D subsurface media (WASH123D: Version 2.0) Technical report CHL-03-XX, Engineer Research and Development Center, US Army Corps of Engineers, Vicksburg, MS

Yeh PJF, Swenson SC, Famiglietti JS, Rodell M (2006) Remote sensing of groundwater storage changes in Illinois using the Gravity Recovery and Climate Experiment (GRACE). Water Resour Res 42. https://doi.org/10.1029/2006wr005374. Accessed December 2018 